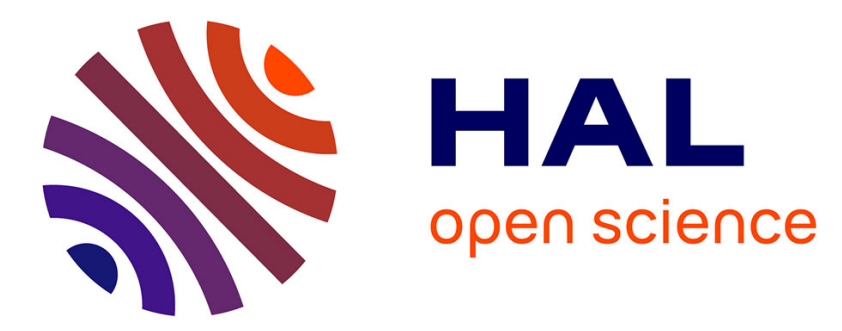

\title{
Cold air outbreaks and their signature in the ozonometric data at the mountain station near Kislovodsk, Russia
}

\author{
N. P. Chakina, A. R. Ivanova, I. N. Kuznetsova
}

\section{- To cite this version:}

N. P. Chakina, A. R. Ivanova, I. N. Kuznetsova. Cold air outbreaks and their signature in the ozonometric data at the mountain station near Kislovodsk, Russia. Atmospheric Chemistry and Physics Discussions, 2004, 4 (1), pp.267-297. hal-00300889

\section{HAL Id: hal-00300889 \\ https://hal.science/hal-00300889}

Submitted on 16 Jan 2004

HAL is a multi-disciplinary open access archive for the deposit and dissemination of scientific research documents, whether they are published or not. The documents may come from teaching and research institutions in France or abroad, or from public or private research centers.
L'archive ouverte pluridisciplinaire HAL, est destinée au dépôt et à la diffusion de documents scientifiques de niveau recherche, publiés ou non, émanant des établissements d'enseignement et de recherche français ou étrangers, des laboratoires publics ou privés. 
Atmos. Chem. Phys. Discuss., 4, 267-297, 2004

www.atmos-chem-phys.org/acpd/4/267/

SRef-ID: 1680-7375/acpd/2004-4-267

(C) European Geosciences Union 2004

\section{ACPD}

4, 267-297, 2004

Cold air outbreaks and their signature in the ozonometric data

N. P. Chakina et al.

\section{Cold air outbreaks and their signature in the ozonometric data at the mountain station near Kislovodsk, Russia}

N. P. Chakina, A. R. Ivanova, and I. N. Kuznetsova

Hydrometeorological Research Centre, Russia

Received: 16 October 2003 - Accepted: 5 January 2004 - Published: 16 January 2004

Correspondence to: N. P. Chakina (chakina@ rhmc.mecom.ru)

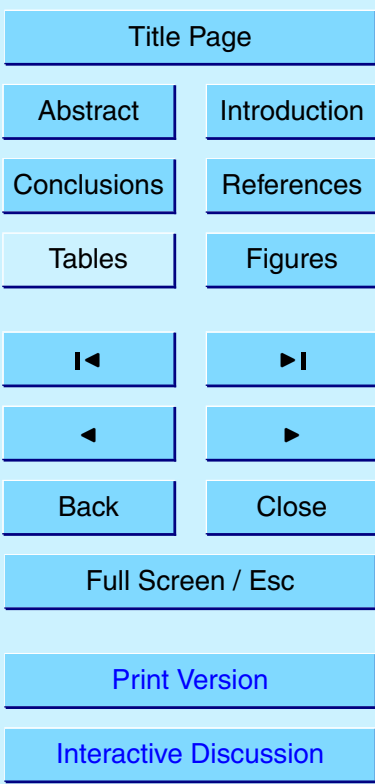

(c) EGU 2004 


\section{Abstract}

Two cases of cold air outbreak in November 2001 are analyzed on the basis of ozone concentration measurements and weather data at the mountain station $\left(43^{\circ} 44^{\prime} \mathrm{N}\right.$, $42^{\circ} 43^{\prime} \mathrm{E}, 2070 \mathrm{~m}$ a.s.l.) near Kislovodsk, North Caucasus, Russia. Two cold fronts, 5 with fast clearing up in the rear of the cloud zone, passed the station in the morning of 12 and 16 November. In both cases, the ozone concentration drops down to $7-8 \mathrm{ppb}$ within the frontal cloud zones, under $100 \%$ relative humidity, $R H$, and then sharply increases to $43-45 \mathrm{ppb}$ in dry ( $R H$ about $50 \%)$, cold air during several hours. After a warm front passage (12 November) or $R H$ growth in the cold post-frontal air(16 November), the ozone concentration decreases again to its average values near $30 \mathrm{ppb}$. Neither diurnal cycle nor photochemical generation could produce in the ozonometric data this specific "drop-and-peak" signature which is considered to be caused by cold outbreak with post-frontal flow of "dry air stream" type.

Synoptic situation and tropopause topography are analyzed using the objective anal15 ysis data and METEOSAT images in the water vapor radiation band. It is concluded that the ozone growth in the rear of the cold fronts is associated with sinking of substratospheric or stratospherically influenced air from the areas of tropopause folding. Motion of cold surges with their frontal zones, jet streams, and tropopause folds is analyzed, including development of wave disturbances at the streamers and formation of substratospheric air "tongues" underflowing the high tropopause and representing "aged" intrusions.

\section{Introduction}

The cold air outbreaks in deep tropospheric troughs and cut-off lows are associated with typical patterns of atmospheric fronts, jet streams and vertical motions. In the frontogenetic baroclinic zones, at the cold sides of jet streams, deep descending motions develop demonstrating themselves in the tropopause folding (e.g. Carlson, 1990;
ACPD

4, 267-297, 2004

Cold air outbreaks and their signature in the ozonometric data

N. P. Chakina et al.

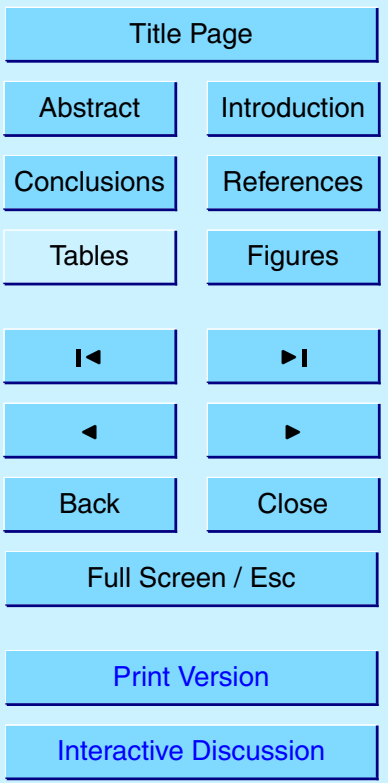

(C) EGU 2004 
Holton et al., 1995). As the upper-tropospheric and stratospheric air is very dry, the low tropopause areas, with their fine structure, are usually well-defined at the satellite images in the water vapor radiation band, WV (Appenzeller, 1996a, b). In the rear of the cold fronts, the conditions are, in principle, the most favorable for stratospheric air 5 penetration to tropospheric levels and down to the surface. In the cold airmass behind the fronts, one can expect to find typical stratospheric air components, such as ozone and certain radioactive isotopes, especially the cosmogenic tracer of Be-7. In fact, a number of cases of increased Be-7 and ozone in the surface air have been described (e.g. Davies and Schuepbach, 1994; Moody et al., 1995; Chakina and Kuznetsova, 10 1997; Cooper et al., 1998).

Unlike Be-7, ozone can be generated by anthropogenic sources which can enhance post-frontal increase in cases of advection from industrially developed areas (Dickerson, 1995). According to the recent study by Cooper et al. (2002), in the midlatitude cyclones, the descending stratospheric (substratospheric) air is represented by "dry air 15 stream" (in agreement with the conceptual model developed by Browning, 1974; Carlson, 1980; Browning and Roberts, 1994). The dry air stream, on average, descends to the levels about $600 \mathrm{mb}$ and always advects stratospheric ozone into the middle and upper troposphere. Other estimates of the stratospheric air penetration depth can be found in Eisele et al. (1999), where it is shown from lidar data that ozone-rich descending air structures in most cases reached $3000 \mathrm{~m}$ a.s.I. On the other hand, Reiter (1991) concluded that the stratospheric intrusions do not penetrate lower than $1600 \mathrm{~m}$ a.s.l. Anyway, their detections at the lower levels are evidently rather rare events.

The dry air stream, which causes the sky clearing immediately after the cold front passage, must be distinguished from the properly post-frontal airstream which can be advected in the lower troposphere from industrial areas and thus can contain anthropogenic pollutants (Cooper et al., 2002).

It can be expected that the effects of dry airstreams connected with the cold fronts are more significant at higher elevations, that is, at the mountain stations. Indeed, as it has been shown in Schuepbach et al. (1999b), in the Alps, at the station of Jungfrau-

ACPD

4, 267-297, 2004

Cold air outbreaks and their signature in the ozonometric data

N. P. Chakina et al.

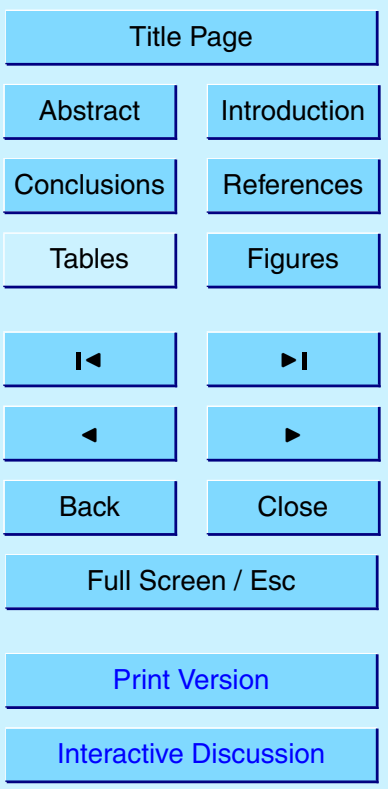

(c) EGU 2004 
joch (3580 $\mathrm{m}$ a.s.I.), ozone increase ("spikes") connected with a tropopause fold is pronounced much more than at another station ( $209 \mathrm{~m}$ a.s.l.) at the leeside of the mountain crest (90 and $65 \mathrm{ppb}$, respectively). At both stations no cloud or precipitation have been reported at the cold front preceding the ozone increase. Also, no impact of 5 planetary boundary layer advection has been revealed, in contrast with Schuepbach et al. (1999a), where it is shown that even at Jungfraujoch elevation, the boundary layer advection of Mediterranean air contributes significantly to the observed ozone levels.

In their comprehensive study of stratospheric intrusion effects at Alpine stations, Stohl et al. (2000) have shown that vigorous stratospheric intrusions can cause ozone 10 peaks to $70-90 \mathrm{ppb}$ in the whole Alpine area along with the northern Apennines. Large extension of the stratospheric air volume at the middle-tropospheric and lowtropospheric levels (as revealed by measurements at the stations at 2165 to $3580 \mathrm{~m}$ a.s.I. and in some valleys) is found to be a result of accumulation of three different stratospheric intrusions. At the three Alpine stations the intrusions manifested themselves also in low relative humidity $(R H)$ and high Be-7 concentrations. Before and after the intrusions (that is, in the frontal zones), high $R H(100 \%)$ was observed along with low (30-40 ppb) ozone. Stohl et al. (2000) use $R H$ in their observational climatology of stratospheric intrusions. However, they note that low $R H$ may be associated with air descended from the upper troposphere undergoing adiabatic warming and thus may be used to identify "stratospherically influenced" air, but it is not a stratospheric tracer. Stohl et al. (2000) came to a conclusion that, in the Alpine region, stratospheric intrusions are significant for the ozone budget: in the boundary layer, their impact is limited, while in the lower free atmosphere, it is of great importance. Much of the stratospheric ozone arrives at the stations strongly diluted with tropospheric air.

$25 \quad$ Taking into account these results, one can expect that sharp cold fronts associated with cold air outbreaks may have a typical signature in the meteorological and ozonometric data: high $R H$ and low ozone ahead and at the front, low $R H$ and increased ozone (not necessarily to stratospheric values) in the rear of the front, in the descending air. This signature can be expected more pronounced at the mountain stations.

\section{Cold air outbreaks and their signature in the ozonometric data}

N. P. Chakina et al.

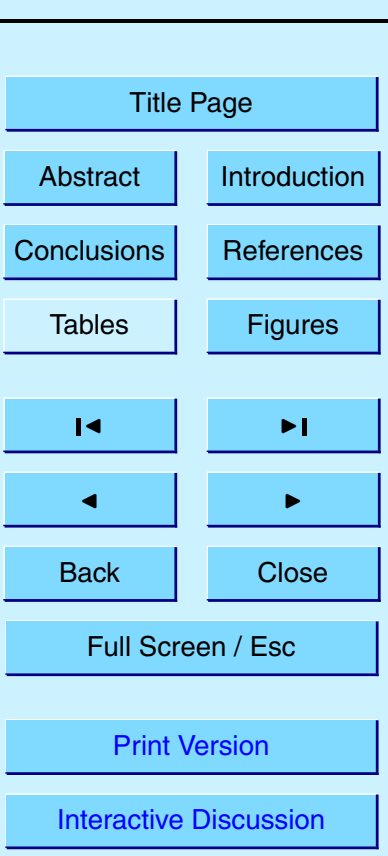


In the paper, two cases of cold air outbreak in November 2001 are analyzed using ozone measurements and weather data in the North Caucasus, Russia, at the Kislovodsk Scientific Mountain Station of the Oboukhov Institute for Atmospheric Physics, Russian Academy of Sciences.

\section{Data and diagnostics}

The station $\left(43^{\circ} 44^{\prime} \mathrm{N}, 42^{\circ} 43^{\prime} \mathrm{E}, 2070 \mathrm{~m}\right.$ a.s.l.) is located $18 \mathrm{~km}$ to the south of the town of Kislovodsk, on a plateau at the northern foothills of the Main Caucasian Ridge (which is about $48 \mathrm{~km}$ distant), in the vicinity of the Caucasian National Park. The region represents a health resort of the Caucasian Mineral Waters; industrial activity 10 is minor and population low. The surface has a general slope to northeast. To the west, foothills of comparable altitude lie at distances of $50 \mathrm{~km}$ and more. (For more information about the station and its instrumentation see Senik et al., 2001).

Hourly data on ozone concentration, 3-h measurements of temperature, $R H$, clouds, visibility, and wind are analyzed. Large-scale atmospheric conditions are diagnosed 15 from 00:00 and 12:00 UTC objective analysis data in the $2.5 \times 2.5^{\circ}$ gridpoints at 16 levels.

From the temperature, wind, and height objective analyses, Ertel potential vorticity, PV, is estimated. Potential temperature and PV vertical profiles are approximated with cubic spline-functions. Still, due to low space resolution of the data and scarcity of the radiosonde network (the only radiosounding station in the North Caucasus is Mineralnye Vody - the Russian for "Mineral Waters"), the resulting PV field can be expected smoothed. The PV field is used to derive the height of dynamic tropopause as a surface of constant PV threshold value. In the previously published works, the PV threshold value varies largely. So, it has been found that the surfaces of $4 \mathrm{pvu}$ (Wirth and Egger, 1999) and 3.5 pvu (Hoinka, 1998; Chakina and Borisova, 1989, 1992) correspond closely to the conventional "thermal" tropopause (WMO, 1957) in the midlatitudes. Lower threshold values have been derived from radioactivity and ozone mea-
ACPD

4, 267-297, 2004

\section{Cold air outbreaks} and their signature in the ozonometric data

N. P. Chakina et al.

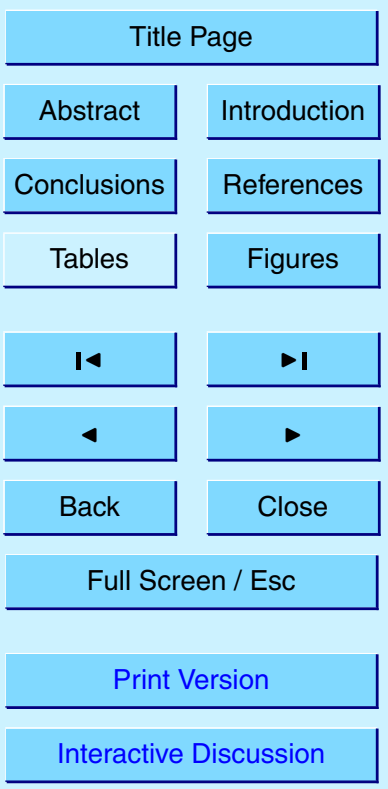

(C) EGU 2004 
surements: Danielsen (1968) and Shapiro (1978) identified the dynamic tropopause as $P V=1 \mathrm{pvu}$, while Stohl et al. (2000) suggest $P V=1.6 \mathrm{pvu}$. It has been also shown that "ozonopause" or "ozone tropopause" is, on average, about $1000 \mathrm{~m}$ lower than the thermal tropopause (Bethan et al., 1996); this fact has been also reflected in (WMO, 5 1986) where ozonopause was admitted to be close to $P V=1.5 \mathrm{pvu}$ surface. To some extent, the PV threshold values depend on space resolution of wind and temperature data under use. In general, it seems to be convenient to consider PV values greater than 2 pvu to be stratospheric (Hoskins, 1991; Holton et al., 1995) and those between 1 and 2 pvu to be intermediate (substratospheric), while PV between 0.8 and 1 pvu can 10 be interpreted as "stratospherically influenced". The surface of 1 pvu thus will represent a "lower dynamic tropopause".

The tropospheric jet stream positions and velocities are derived from the field of maximum winds computed using spline-approximated profiles of wind components at the gridpoints.

15 The frontal parameter, $F$, is diagnostically estimated in the gridpoints. The frontal parameter has been introduced in (Chakina et al., 2000, 2001) for the purpose of objective detection of frontal zones and represents a measure of pressure field curvature and baroclinicity in the lower half of the troposphere. Results and findings of (HuberPock and Kress, 1989) have been taken into account by Chakina et al. $(2000,2001)$. The frontal parameter is computed in two steps:

1. The surface pressure field topography is objectively classified into the following 23 classes: center and 8 sectors (corresponding to 8 points of compass) of the low; trough; center and 8 sectors of the high; ridge; saddle; rectilinear isobars; lowgradient field. The classification is carried out through estimation of correlation rate between the pressure data in the area of $4 \times 4$ gridpoints (with the considered gridsquare in the center) and each of "standard fields" representing the classes. Among the obtained correlation rates $>0,7$, a maximum is selected, and the pressure field in the central gridsquare is attributed to the corresponding class.

ACPD

4, 267-297, 2004

Cold air outbreaks and their signature in the ozonometric data

N. P. Chakina et al.

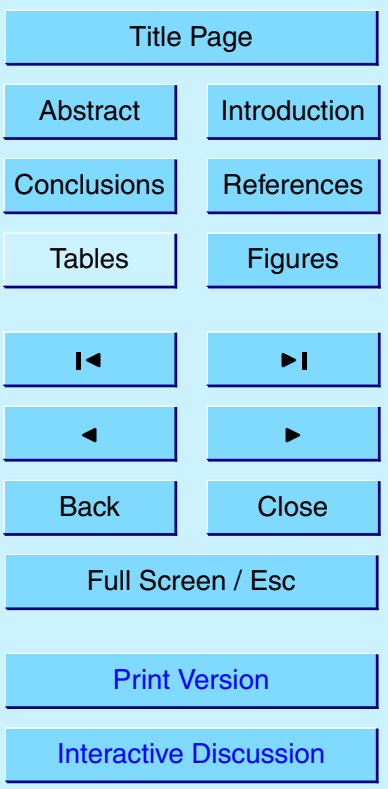

(c) EGU 2004 
2. Calculation of $F$ (dimensionless) as a linear function of two "predictors" which are different for different classes. The main predictors are:

ACPD

4, 267-297, 2004

$\left|\nabla Z T E_{850}^{500}\right|, \quad\left|\nabla Z T E_{925}^{700}\right|, \quad \mid \nabla T_{\text {surfacel }}$,

$|\nabla| \nabla Z T E_{850}^{500}||, \quad|\nabla| \nabla Z T E_{925}^{700}||,\left|\nabla T_{e 850}\right|$,

$5\left|\nabla T_{850}\right|,\left|\nabla T_{925}\right|,\left|V_{850} \cdot \nabla T_{850}\right|$,

$\nabla^{2} H_{925}^{\prime} \quad \nabla^{2} H_{850}$

In total, 12 predictors are involved as describing temperature, humidity, height, and wind fields in the lower half of the troposphere.

In Eq. (1), ZTE is equivalent thickness (Huber-Pock and Kress, 1989):

$Z T E=-\sum_{P_{l}}^{P_{u}} \frac{R}{g} \overline{T_{e}} \ln \frac{P_{u}}{P_{l}}$

- a quantity depending on equivalent temperature, $T_{e}$, distribution in the layer from $P_{I}$ to $P_{u}: P_{u}=500$ or $700 \mathrm{mb}, P_{l}=850$ or $925 \mathrm{mb}$,

$T_{e}=T+L q / c_{p}$,

$\bar{T}_{e}=\left(T_{e, u}-T_{e, l}\right) /\left(\ln T_{e, u}-\ln T_{e, l}\right)$,

$15 q$ is specific humidity, $\boldsymbol{V}$ - wind velocity, $L-$ evaporation heat, $c_{p}$ - air specific heat under constant pressure.

The frontal parameter thus defined is found to be a good indicator of the frontal zones: the $F$ contours produce two-dimensional picture of the surface frontal zones of finite width and quantitatively estimated sharpness (intensity). The areas with $F<20$ are considered to be occupied by homogeneous airmasses or by those with low baroclinicity; $F \geq 20$ - zones of atmospheric fronts, $F \geq 60$ - zones of sharp atmospheric fronts.

Finally, the WV images from METEOSAT are also included into consideration.
Cold air outbreaks and their signature in the ozonometric data

N. P. Chakina et al.

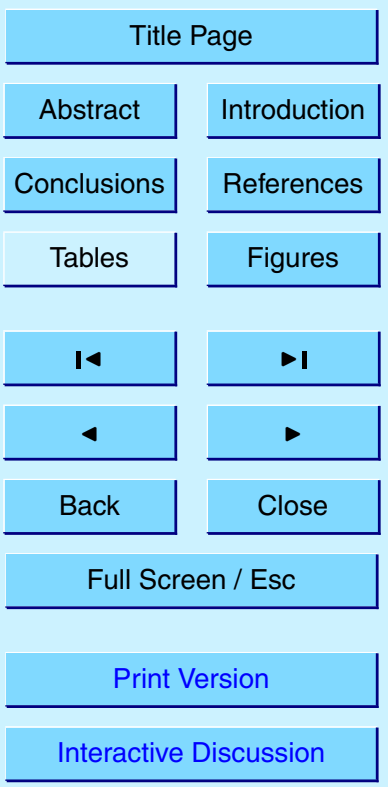

(c) EGU 2004 


\section{Surface observations}

In November 2001, two periods are observed (from 00:00 UTC 12 November to 09:00 UTC 13 November and from 03:00 UTC 16 November 02:00 UTC 17 November) with rather similar changes in ozone concentration (Fig. 1): a sharp drop (from 35 and 5 25-30 ppb on 12 and 16 November, respectively, to 7-8 ppb) and then a sharp growth (to 45 and $43 \mathrm{ppb}$, respectively). The ozone levels above $40 \mathrm{ppb}$ are observed during 12 and $6 \mathrm{~h}$ on 12 and 16 November, respectively. Note that in both cases the ozone maxima are registered in the nighttime or in the early morning (local time is $3 \mathrm{~h}$ ahead UTC). Also, note that no diurnal cycle of ozone concentration is observed during the whole period shown in Fig. 1.

The increased ozone periods correspond closely enough to those of low RH (4856 and $<50 \%$ on 12 and 16 November, respectively), and ozone drops - to high $R H$ (100\%). However, on 12 November, the ozone drop starts at 00:00 UTC, while $R H=100 \%$ is registered already at 12:00 UTC on 11 November, along with fog and $200-500 \mathrm{~m}$ visibility (no data are available on precipitation or fog/cloud microphysics). The whole day of 11 November air temperature is positive; in the night and morning, it drops to $-4.2^{\circ} \mathrm{C}$ at 06:00 UTC (that is, at 09:00 LT) of 12 November and keeps negative till the end of the period of increased ozone. Evidently, a cold front passes in the night of 11 to 12 November and a warm one - in the morning of 13 November: temperature remains positive, after 06:00 UTC on 13 November, during next three days, with a maximum of $10.1^{\circ} \mathrm{C}$ on 14 November. All this time, a homogeneous airmass (with westerly winds to $6 \mathrm{~m} / \mathrm{s}$, not shown) occupies the area. The airmass is dry enough $(\mathrm{RH}<70 \%$ almost during the whole days of 13 and 14 November); not before the evening of 16 November, $R H$ grows to $90 \%$. On 15 November, cold advection appears: temperature decreases, convective clouds develop (in the daytime, $\mathrm{Cu}$ and $\mathrm{Cb}$ clouds are registered several times). In the morning of 16 November, another cold front passes, with $\mathrm{Cb}$ clouds and $R H=100 \%$. Then, the sky clears up, and the dry airmass comes with a new peak of ozone.

\section{ACPD}

4, 267-297, 2004

Cold air outbreaks and their signature in the ozonometric data

N. P. Chakina et al.

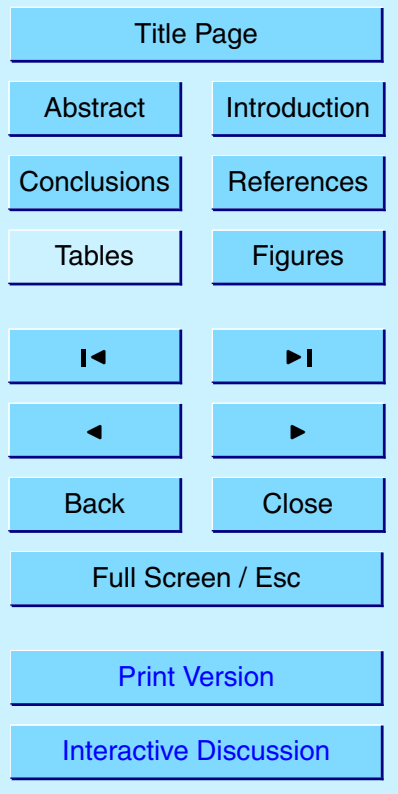

(c) EGU 2004 
In both cases, typical changes in ozone concentration ("drop-and-peak") are associated with cold fronts. The ozone drops are observed just in the zone of frontal clouds and $R H=100 \%$, the peaks correspond to clear sky and dry, cold air (in the nighttime!). On 12 November, the increased ozone period ends with the warm front passage; on 16 5 November, the end of increased ozone is associated with $\mathrm{RH}$ increase and convective activity development, evidently caused by secondary fronts in the post-frontal airmass. Indeed, the cold advection continues, and air temperature keeps decreasing (down to $-16.2^{\circ} \mathrm{C}$ at 06:00 UTC 18 November).

So, the surface observations show that

- both cold fronts exhibit the same signature in the ozonometric (and $R H$ ) data;

- the warm front has no such signature;

- ozone concentration increases directly after cold front passage, in the dry and cold airmass; when cold, but moist air, or dry, but warm one comes, - ozone concentration decreases to its background value.

\section{Tropopause topography}

To describe the tropopause topography, the $P V=1 \mathrm{pvu}$ surface - lower dynamic tropopause - is used along with WV satellite images. In the gridpoints with vertical $\mathrm{PV}$ profiles containing more that one level with $\mathrm{PV}=1 \mathrm{pvu}$, the upper of these levels is taken to construct the tropopause charts. The volumes with $P V \geq 1$ pvu found at lower

20 levels are shown in the cross-sections of $\mathrm{PV}$ and equivalent potential temperature, $\theta_{e}$ (see Sect. 7).

In Figs. 2, 3, pressure at 1 pvu surface at 00:00 and 12:00 UTC is displayed along with WV images available at the nearest time. In Figs. $2 a$ and c, a characteristic pattern of waves (or vortices) can be seen on the dry air band, oriented from north-east to
ACPD

4, 267-297, 2004

Cold air outbreaks and their signature in the ozonometric data

N. P. Chakina et al.

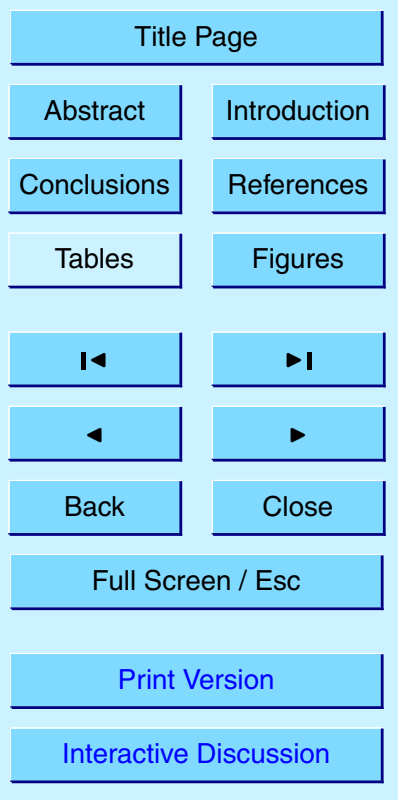

(C) EGU 2004 
south-west, as a clear manifestation of hydrodynamic instability. According to the satellite data between the objective analysis times (not shown), the waves developed about 14:30 UTC on 11 November. In the rear sector of one of the waves, maximum sinking (the darkest area in the WV image, Fig. 2a at 00:00 UTC 12 November is observed to 5 the west of the station. Respectively, the leading sector of the wave - and, probably, originating lifting - is associated with a lighter area to the east. In Fig. $2 \mathrm{~b}$ maxima of pressure at $1 \mathrm{pvu}$ - that is, tropopause funnels - correspond to the sinking areas of two vortices in Fig. 2a. At 12:00 UTC (Figs. 2c and d), the station position is near the west edge of the dark area at WV image and of the tropopause funnel.

10 At 02:30 UTC of 12 November (Fig. 2a), two secondary dark bands are seen at the WV image, in the rear of the primary one. A narrow band, also with wavelike disturbances, is oriented approximately along $50^{\circ} \mathrm{N}$ to the west of Kiev, then it turns to the north-east and lies to the north of Volgograd and to the south of Nizhny-Novgorod. This band, apparently having no counterpart in the PV field, will be considered as in15 termediate between the primary streamer and the arch-shaped dry band oriented from Stockholm to Riga, Moscow, and Syktyvkar and corresponding to the deep streamer in Fig. 2b.

On 16 November (Fig. 3), the stratospheric streamer is deep and well-defined at 00:00 UTC and 02:30 UTC. Hydrodynamic instability in this case also develops, though not so pronounced; longer (as compared with Fig. 2) waves can be seen along the streamer. About 12:00 UTC (Figs. $3 \mathrm{c}$ and d) the streamer, to a large extent eroded by wave instability, has evidently passed the station. Unlike on 12 November, only the leading sector of the wave (and not its rear sector) - and thus an area of weaker sinking or even originating lifting in certain layer - passes over the station.

At 02:30 UTC of 16 November (Fig. 3a), a very distinct arch of dry air is observed at a slightly southern position than the analogous feature in Fig. $2 \mathrm{a}-$ from the Gulf of Bothnia to Riga, Minsk, and Moscow. At 12:00-12:30 UTC (Figs. 2c and d), this archshaped tropopause fold approaches the coasts of the Black and Azov Seas. Again, note a general good agreement between the WV and PV-derived locations of the
ACPD

4, 267-297, 2004

\section{Cold air outbreaks and their signature in the ozonometric data}

N. P. Chakina et al.

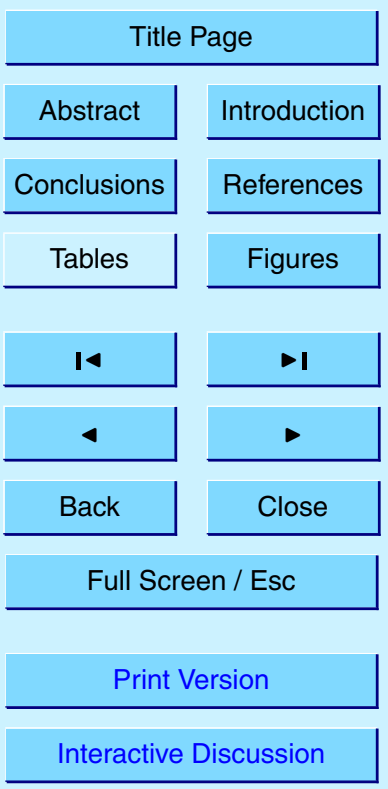

(c) EGU 2004 
tropopause folds.

So, in both cases - on 12 and 16 November - the tropopause folds, subject to wave instability, passed over the station between 00:00 and 12:00 UTC, that is, immediately after the cold front passages as determined from Fig. 1. However, as it can be seen 5 both from WV and PV pictures, the fold passages and the ozone peaks are not synchronous. Indeed, the ozone maxima are reached at 23:00 and 19:00 UTC on 12 and 16 November, respectively, while at 17:30 and 12:30 UTC, respectively, the station lies in the rear of the tropopause folds.

\section{Surface fronts}

10 The surface frontal zones (computed within 30 to $70^{\circ} \mathrm{N}$ latitude band) and the 700 $\mathrm{mb}$ height and temperature are shown in Fig. 4. The frontal zones outlined by $F=20$ contours are well-defined ( $F>100$ in the maxima). The cold air outbreaks on 12 and 16 November have clear similar features: rather narrow tongues of cold air are oriented to the east Black Sea (12 November, Fig. 4b) and to the Azov Sea and central 15 Black Sea (16 November, Fig. 4d), in the rear of the tropopause folds. In the deep low with a center over the Cola Peninsula on 12 November and to the south of the White Sea on 16 November, occlusions and cold fronts correspond to the rear, arch-shaped tropopause folds. Two cold air surges are observed in both cases, associated with two frontal systems and two tropopause folds. Apparently, the intermediate dry air band 20 from Fig. 2a (sketched in Fig. 4b) does not correspond to any separate frontal zone at the surface.

\section{Jet streams}

The tropospheric jet streams are parallel to the surface fronts and the tropopause folds (Fig. 5). Yet, they are shifted to the rear of the cold fronts, while the tropopause folds

\section{ACPD}

4, 267-297, 2004

Cold air outbreaks and their signature in the ozonometric data

N. P. Chakina et al.

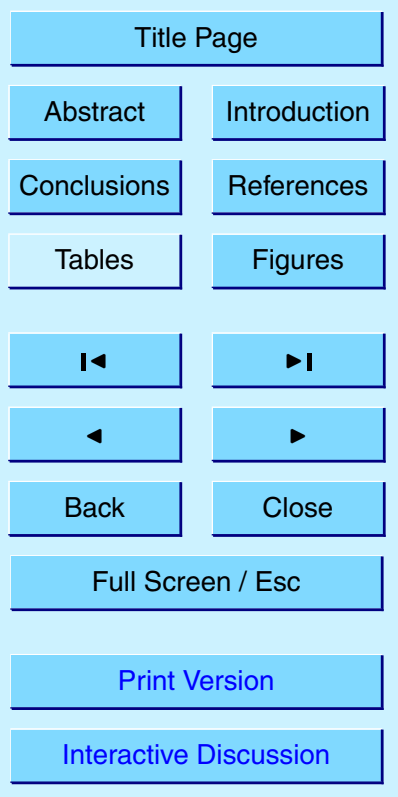

(c) EGU 2004 
are shifted, with respect to the jet stream axes, to the cold airmass. Thus, sinking motions are associated with cold sides of the jet streams. Over the area under study, on 12 November, maximum winds do not reach $30 \mathrm{~m} / \mathrm{s}$ - a threshold value for the tropospheric jet stream; on 16 November, the maximum winds here but slightly exceed $530 \mathrm{~m} / \mathrm{s}$. The strong jet streams (>50 and $>80 \mathrm{~m} / \mathrm{s}$ on 12 and 16 November, respectively) are associated with the second cold surges and the arch-shaped tropopause folds.

\section{Vertical cross-sections}

For 12:00 UTC 12 November, zonal and meridional cross-sections of PV and $\theta_{e}$ fields are shown in Fig. 6. The surface topography profiles are taken from the Terrain Base CD-ROM Version 1.1 (1995), National Geophysical Data Center, Boulder, CO, USA, with 10-minute resolution. The profiles shown in the cross-sections represent well topography of the area, though position of the station at the terrain is given roughly.

The isentropes outline a cold airmass of limited dimension over the Caucasus, along the latitude circle (Fig. 6a). In the meridional cross-section (Fig. 6b), the baroclinic zone 15 appears near $40-45^{\circ} \mathrm{N}$ as connected with the cold surge and corresponds to the cold front which, at this time, already has passed the station. In the middle troposphere, warm advection zone comes to the station (Fig. 6a): the winds are mainly westerly this time in the troposphere over the region. Another zone of steeply sloped isentropes exists in the upper half of the troposphere near $55^{\circ} \mathrm{N}$ (not shown), corresponding to the second cold surge. In agreement with $\theta_{e}$ field, a tropopause fold over the station is displayed in Figs. $6 a$ and $b$; another fold associated with the second cold surge is partly shown in Fig. $6 \mathrm{~b}$ at $52.5-55^{\circ} \mathrm{N}$. The tropopause fold over the station is funnel-shaped, its lower part being sloped to the northwest with respect to the upper one. Due to this "lag" of the lower part of the funnel, its air could influence the ozonometric data during several hours after 12:00 UTC. The lower dynamic tropopause descends below $2500 \mathrm{~m}$ a.s.l..

The situation of 12 November is rather simple: a local 1 pvu-tropopause funnel, con-

Cold air outbreaks and their signature in the ozonometric data

N. P. Chakina et al.

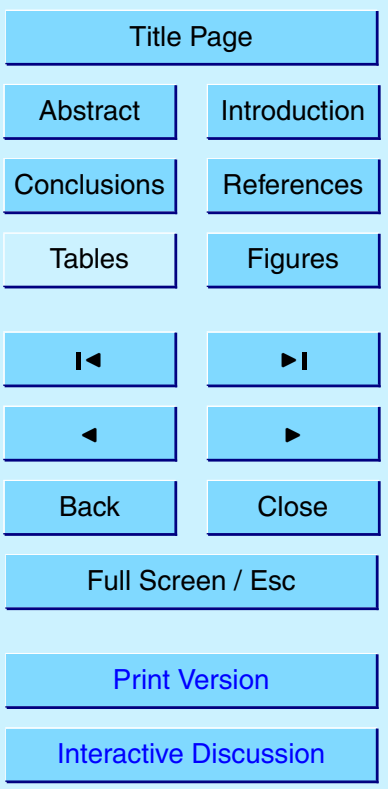

(C) EGU 2004 
taining substratospheric air, passed over the station immediately after the cold front cloud band, that is, about 12:00 UTC. The funnel evidently does not reach the level of the station: the computed height of $P V=1$ pvu is several hundred meters above. However, taking into account possible smoothing of the funnel due to low resolution (and 5 scarce radiosonde network in the area), we may conclude that stratospherically influenced air did reach the station and left its signature in the ozonometric and hygrometric data, before being replaced by warmer tropospheric air.

The case of 16 November is more complicated, though many features of similarity exist. In Fig. 7a, the station is in the cold airmass, to the west of the baroclinic zone. No 10 continuous tongue of substratospheric air can be seen in the zonal cross-section. At the meridional cross-section (Fig. 7b), two baroclinic zones corresponding to two cold surges are displayed, as well as two tropopause folds.

The main difference is connected with the substratospheric tongue shape. So, on 12 November, the tongue of air with $P V \geq 1$ pvu is well-defined and evidently connected 15 with the tropopause fold which, according to Fig. 2, is situated this time over the station. On 16 November, the tongue is less pronounced (at least in the zonal cross-section, Fig. 7a). From the meridional cross-section (Fig. 7b), one can conclude that the stratospherically influenced air, which could cause increased ozone, is connected not with the first cold surge, but with the second one. The lower part of the tongue of air with 20 $\mathrm{PV} \geq 1 \mathrm{pvu}$ in Fig. $7 \mathrm{~b}$ is stretched to the west with respect to the tropopause fold (as viewed from above) for about $250 \mathrm{~km}$ and represents a quasi-horizontal layer in the middle troposphere, underlying and overlying the tropospheric air. Indeed, this air with $\mathrm{PV} \approx 1$ pvu could affect the ozone measurements in the afternoon of 16 November and the next night.

25 Figure 8 helps one to reveal the three-dimensional view of PV field. Low vertical resolution of the data does not allow us to retrieve vertical structure in detail. Yet, some interesting features can be noted. The areas of increased PV at each level are stretched from south-west to north-east. It seems that the areas of high PV at 300 and $400 \mathrm{mb}$, in the north-west parts of the plots, correspond to deep tropopause fold

ACPD

4, 267-297, 2004

\section{Cold air outbreaks and their signature in the ozonometric data}

N. P. Chakina et al.

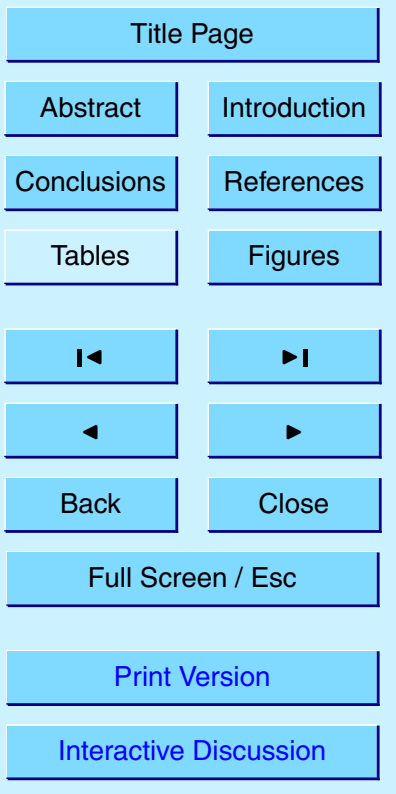

(c) EGU 2004 
(Fig. 3) near $50-52^{\circ} \mathrm{N}$ and $40-45^{\circ} \mathrm{E}$, which appears also at $500 \mathrm{mb}$ surface in Fig. 8 as contoured by $P V=1$ and $1.5 \mathrm{pvu}$. Also, at the $700 \mathrm{mb}$ level in Fig. 8, the contours of 1 and $1.5 \mathrm{pvu}$ are evidently connected with those at $500 \mathrm{mb}$.

So, analysis of the cross-sections leads us to the following results:

5 In both cases, two baroclinic zones are revealed associated with two cold surges; the tropopause folds correspond to their baroclinic zones. Between the two surges, warmer air can be observed which manifests itself as a trough of isentropes. This feature is well-defined on 12 November and but slightly marked in the middle troposphere on 16 November.

10 On 12 November, a deep local tropopause funnel, developed in the rear of the wave on the streamer, passes over the station, bringing the stratospherically influenced air. In the afternoon of 12 November and during the next night, a tongue of this air drags behind the tropopause funnel, as viewed from above both at WV and PV images.

On 16 November, the tongue of stratospherically influenced air, which could cause 15 increased ozone, is apparently connected not with the first cold surge, but with the second one. The lower part of the tongue seems to be displaced to southwest with respect to the tropopause funnel (as viewed from above) for a distance about $250 \mathrm{~km}$.

\section{Trajectories}

The isentropic trajectories produced (on the basis of reanalysis) by NOAA Air Research 20 Laboratory are used to estimate the air particle motion. The backward 5-day trajectories ending at different levels above the station and in its vicinity (not shown) indicate that the air, which occupied the area on 12 and 16 November at 12:00 UTC and the next $12 \mathrm{~h}$, was descending from upper-tropospheric and substratospheric levels to the middle troposphere, down to the level of the station.

25 In Fig. 9, the trajectories ending at 12:00 UTC in 4 points surrounding the station at $200 \mathrm{~m}$ a.s.I., are shown. Elevations of the points vary from 370 to $3700 \mathrm{~m}$ a.s.l.; the point of $43^{\circ} \mathrm{N}, 42^{\circ} \mathrm{E}$ elevation is close to that of the station.

\section{Cold air outbreaks and their signature in the ozonometric data}

N. P. Chakina et al.

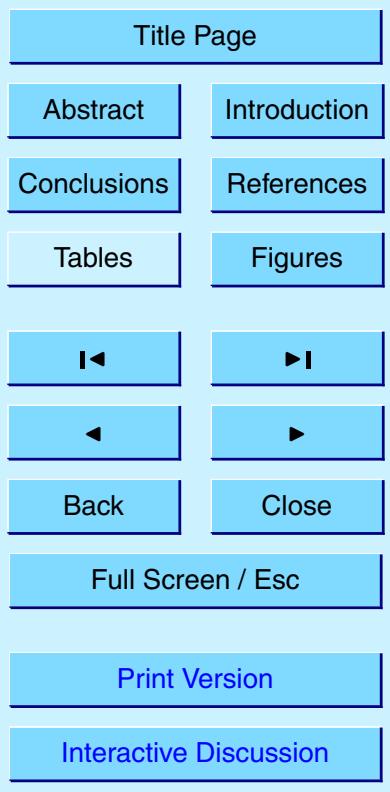

(C) EGU 2004 
It is interesting to note that the trajectories for 12 November exhibit very fast sinking on 9 November (from $8-10$ to $3-5 \mathrm{~km}$ ), but slow descent during last $24 \mathrm{~h}$. That is, the particles descended over the Atlantic in the layer with strong winds (jet stream). On 8 November, 00:00 UTC, all 4 particles are found at the west coast of the streamer over 5 the Atlantic (not shown). During next $12 \mathrm{~h}$, the trajectories converge, and the particles descend along the slope of the streamer (to the south of the Ireland). Later, they sink to the bottom of the funnel (which develops on the streamer) and move, with the latter, horizontally over Europe approaching from northwest the area under study. On 16 November, on the contrary, the descent was fast during last three days, from 6-8 km 10 levels. The start points, 5 days ago, are at $8-10 \mathrm{~km}$ levels. The trajectory 1 (Fig. 9, right) with the ending point slightly to the north, comes from the Atlantic, while three other trajectories come from Europe and then the Mediterranean. All they travel in the areas of high tropopause and then descend and join each other in the main streamer.

\section{Discussion}

15 Aiming to reveal causes of ozone concentration changes on 12-13 and 16-17 November 2001, we study atmospheric processes in these two cases which have much in common, though significant differences also exist.

Sharp drops in ozone concentration (to 7-8 ppb) associated with cold front passages in the night of 11-12 November and in the morning of 16 November, accompanied by

$20 R H=100 \%$ and overcast weather, have succeeded by fast clearing up, ozone growth to 43-45 ppb and $R H$ decrease. These features are observed in nighttime or early in the morning, so that photochemical generation of ozone could not contribute significantly. Ozone concentrations above $40 \mathrm{ppb}$ are registered during 12 and $4 \mathrm{~h}$ on 12 and 16 November, respectively, and then decrease after warm front passage (12 November) or after $R H$ increase in the tropospheric cold post-frontal airmass (16 November). Between the two periods of sharp changes, ozone concentration varies near the level of $30 \mathrm{ppb}$.
ACPD

4, 267-297, 2004

\section{Cold air outbreaks and their signature in the ozonometric data}

N. P. Chakina et al.

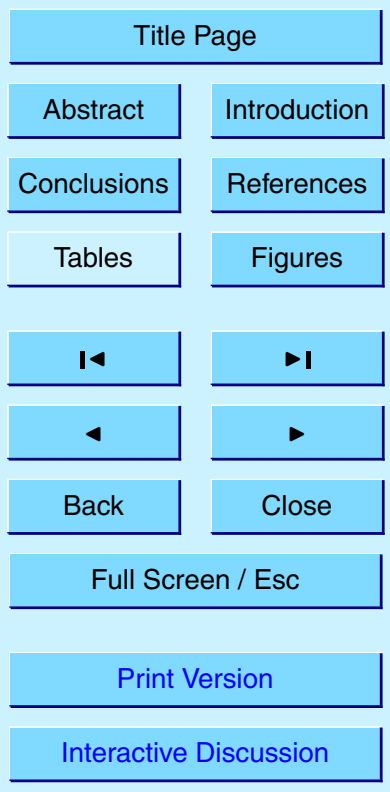

(c) EGU 2004 
The ozone peaks are not high, and the maximum values are not stratospheric. However, against the background of rather homogeneous ozone, with no diurnal cycle, the two similar "drop-and-peak" events associated with cold fronts can be considered to be signatures of the fronts in the ozonometric data. The cold fronts in both cases are 5 characterized with narrow cloud zones and, evidently, with pronounced sinking motions in the immediate rear of the fronts. Analysis of synoptic-scale flows shows that deep descending motions associated with cold air outbreaks took place in both cases.

During the period from 11 to 17 November, over the European Region, a deep trough in the troposphere is observed as oriented from the Cola Peninsula to the south. By 1016 November, the trough deepens and takes a shape of upside-down omega. Several cold surges, with their baroclinic frontal zones, originate in the west part of the trough. The cold surges are separated by volumes of air with lower baroclinicity. So, about 00:00 UTC of 12 November, a cold surge with its front passes over the ozonometric station near Kislovodsk; the cold airmass comes from the west. At the WV images, a 15 bar and of dry air behind the cold front is oriented to north-east over the area under study. The front and the streamer are subject to baroclinic instability: two waves (or vortices) develop, with their centers (at 02:30 UTC) near Mineral Waters and Samara. In the surface pressure field, small, weak troughs correspond to the waves. Typical vertical circulation develops in the unstable waves: descending branches in their rear (cold) sectors can be considered as embryonic "dry air stream", while in the warm sectors, embryonic "warm conveyor belts" cause moist advection and diffusion of the streamer. Well-defined zones of sinking in the cold sectors of the waves generate deep funnels of dynamic tropopause. One of the funnels is situated in the area under consideration. In the rear of the cold surge, a volume of warmer air moves from the west near the surface 25 and in the free troposphere, followed by the second cold surge with the corresponding zone of descending air. This zone manifests itself at the WV images as an arch-shaped band from Stockholm to Riga - Moscow - Syktyvkar.

Time of the funnel passage over the station on 12 November (as it can be revealed both from WV images and PV field) is in a good agreement with beginning of ozone
ACPD

4, 267-297, 2004

\section{Cold air outbreaks and their signature in the ozonometric data}

N. P. Chakina et al.

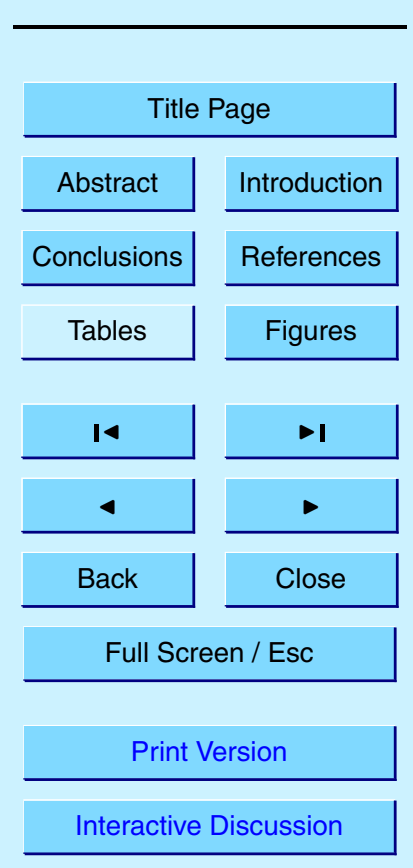

(C) EGU 2004 
growth at the surface, in the dry and cold air. The cross-sections for 12:00 UTC reveal an isolated, deep funnel, rather typical in shape. Its motion in the middle troposphere is slower than above. As a result, a "tail" or tongue of substratospheric and stratospherically influenced air is formed upstream of the tropopause funnel as viewed from above.

5 This tail passes over the station during late afternoon of 12 November and next night, causing low $\mathrm{RH}$ and increased ozone. Horizontal size of the tongue in zonal direction (that is, approximately in the direction of airflow) is of order of $200 \mathrm{~km}$. Note that the tropopause fold associated with the second cold surge this day also has its own tail stretched to the south of the fold viewed from above.

10 On 16 November, the situation has much in common. A sharply defined streamer, outlining the rear of the cold surge, is stretched from south-west to north-east over the area under study. The front is also unstable, with longer wavelength of the slowly growing disturbances. A segment of cold front which passes over the station is associated with the leading part of the wave (embryonic warm conveyor belt). As a result, the 15 streamer contours are diffuse in this area, the streamer itself less dark at WV images, and the tropopause fold not deep: its bottom is at about $6 \mathrm{~km}$ a.s.l., and no response to its passage can be revealed in the ozonometric data at the station.

To the north of this streamer, the second cold surge is well-defined with its tropopause fold, stretched, as a distinct arch, from the Gulf of Bothnia to Riga, Minsk, and Moscow. The tongue of stratospherically influenced air, which could cause increased ozone, is apparently connected with this second cold surge. The lower part of the tongue is stretched for about $250 \mathrm{~km}$ as a quasi-horizontal layer of slightly increased $\mathrm{PV}$ in the middle troposphere.

The 5-day backward trajectories show that the air which seems to cause increased ozone was subject to intense sinking. So, the air particles, which reached the area under study on 12 November at 12:00 UTC, descended from $8-10 \mathrm{~km}$ agl to $3-5 \mathrm{~km}$ during 9 November over the Atlantic and later descended but slowly. That is, this air (stratospheric or substratospheric at the initial points of the trajectories) was transferred in the middle troposphere during last 2-3 days. This result can be considered as an
ACPD

4, 267-297, 2004

\section{Cold air outbreaks and their signature in the ozonometric data}

N. P. Chakina et al.

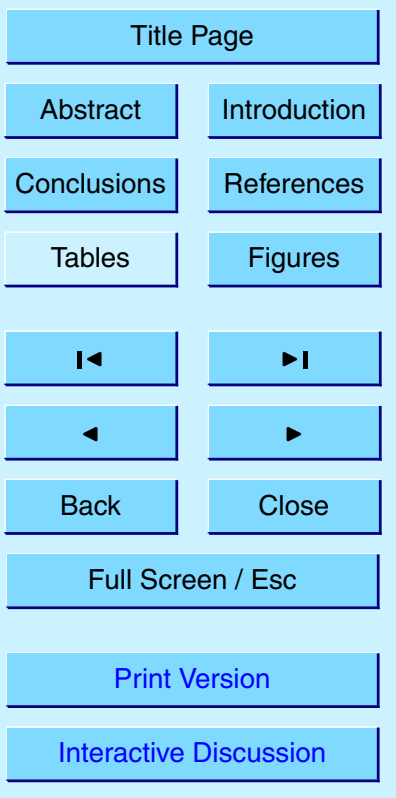

(c) EGU 2004 
illustration of a comment in (Stohl et al., 2000) about "indirectly intruding stratospheric air" which travels horizontally over some period and thus loses, to some extent, its stratospheric properties.

On 16 November the air also descended from the upper troposphere and lower 5 stratosphere; the fastest sinking occurs during last 3 days. In both cases, evidently, the air causing increased ozone in the rear of the cold fronts can be considered as "aged" stratospheric intrusions.

\section{Conclusions}

The following conclusions can be drawn from the analysis of two cases of sharp changes in ozone concentration at the mountain station near Kislovodsk.

At the station, situated at $2070 \mathrm{~m}$ a.s.I., rather typical narrow cold fronts with fast clearing-up in the rear of cloud zone, are associated with a characteristic "drop-andpeak" signature in the ozonometric data, along with high $(100 \%)$ and low (about $50 \%) R H$. Neither diurnal cycle nor photochemical generation could produce these specific changes in ozone and $R H$. They are evidently caused by descending motions transporting substratospheric or stratospherically influenced air from the areas of tropopause folding.

The tropopause folds, developing at the cyclonic sides of tropospheric jet streams, in the baroclinic zones of cold air deep outbreaks, in the cases under study are not too 20 deep: the surface of $\mathrm{PV}=1 \mathrm{pvu}$, that is, the lower dynamic tropopause, does not reach $850 \mathrm{mb}$ level. However, the cross-sections of PV field (apparently too smoothed due to scarcity of data) show that the stratospherically influenced or substratospheric air could reach the area of the station at the time corresponding to the ozone peaks. This air came to the station within the "tongues" or "tails" stretched from the tropopause folds as viewed from above both at WV images and at dynamic tropopause maps. These tongues intrude tropospheric levels and flow under the overlying upper-tropospheric air. Apparently, they can flow far from their tropopause folds (viewed from above) - for

Cold air outbreaks and their signature in the ozonometric data

N. P. Chakina et al.

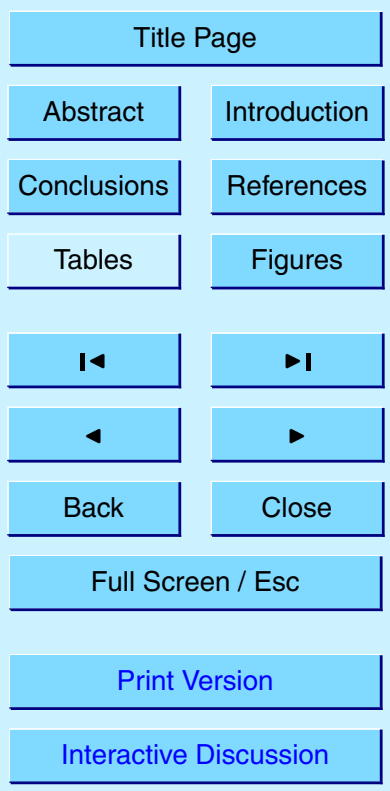

(c) EGU 2004 
distances about $250 \mathrm{~km}$. These volumes of air with slightly increased ozone and PV and with low $R H$ seem to represent "aged" stratospheric intrusions. This air traveled in the troposphere during last 2-3 days, after descending from the levels of 8-10 km.

The shape of the streamers outlining the cold outbreaks and lying behind their fronts

5 is highly sensitive to hydrodynamic instability of the baroclinic frontal zones. In both cases, wave disturbances are clearly seen at the WV images and at the dynamic tropopause maps. In the rear sector of the wave, a deep tropopause funnel can develop (the case of 12 November) as a result of strong sinking. This effect can be interpreted as that of incipient dry air stream. In the leading part of the wave, a counterpart effect 10 of incipient warm conveyor belt leads to slowing down of the tropopause folding and to diffusion of the streamer. As a result, the fold here does not penetrate the middle troposphere (the case of 16 November). The process of origination and growth of the unstable waves is almost undistinguishable in the pressure field and, at the same time, exceptionally well-defined at the WV images and dynamic tropopause maps. This fea15 ture represents a further confirmation of the conclusion by Hoskins (1991) and Hoskins et al. (1985) about high potential of PV-analysis of real weather systems.

Acknowledgements. This work was supported by INTAS Grant 01-0016. The authors are also thankful to the Oboukhov Institute for Atmospheric Physics, Russian Academy of Sciences (personally, N. F. Elansky and I. A. Senik) for the surface ozone and weather data from the Kislovodsk Mountain Scientific Station; to the NOOA Air Research Laboratory for making available the air parcel trajectories from their Internet site; and to G. Yu. Kalugina for graphic work.

\section{References}

Appenzeller, C., Davies, H. C., and Norton, W. A.: Fragmentation of stratospheric intrusions, J. Geophys. Res., 101, 1435-1456, 1996a.

Appenzeller, C., Holton, J. R., and Rosenlof, K. H.: Seasonal variation of mass transport across the tropopause, J. Geophys. Res., 101, 15 071-15078, 1996b.

Bethan, S., Vaughan, G., and Reid, S. J.: A comparison of ozone and thermal tropopause

Cold air outbreaks and their signature in the ozonometric data

N. P. Chakina et al.

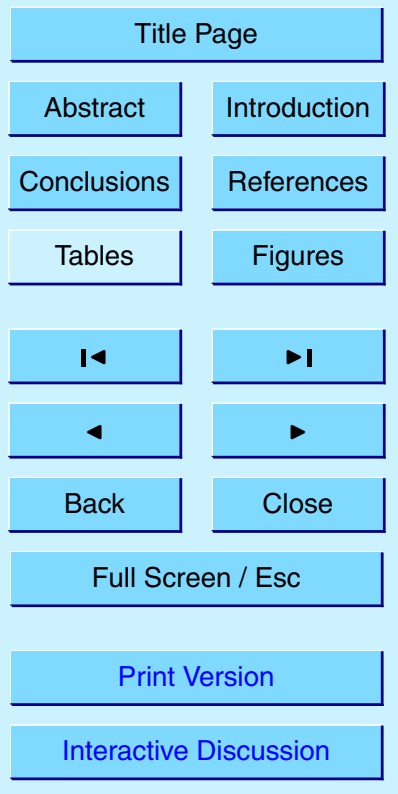

(C) EGU 2004 
heights and the impact of tropopause definition on quantifying the ozone content of the troposphere, Quart. J. Roy. Meteorol. Soc., 122, 929-944, 1996.

Browning, K. A.: Mesoscale structure of rain systems in the British Isles, J. Meteorol. Soc. Japan, II, 52, 314-327, 1974.

5 Browning, K. A. and Roberts, N. M.: Structure of a frontal system, Quart. J. Roy. Meteorol. Soc., 120, 1537-1557, 1994.

Brunner, D., Staehelin, J., Jeker, D., Wernli, H., and Schumann, U.: Nitrogen oxide and ozone in the tropopause region of the Northern Hemisphere: measurements from commercial aircraft in 1995/1996 and 1997, J. Geophys. Res., 106, D21, 27 673-27 700, 2001.

10 Carlson, T. N.: Airflow through midlatitude cyclones and the comma cloud pattern, Mon. Weather Rev., 108, 1498-1509, 1980.

Carlson, T. N.: Mid-latitude weather systems, HarperCollins Acad., 507, 1991.

Chakina, N. P. and Borisova, V. V.: Using potential vorticity to compute the tropopause height and temperature. Proc. Hydrometeorol, Centre Russia, 305, 98-117, in Russian, 1989.

Chakina, N. P. and Borisova, V. V.: Experience of potential vorticity application to compute the tropopause height, Russian Meteorol. Hydrol., 9, 57-65, 1992.

Chakina, N. P. and Kuznetsova, I. N.: Increased total beta-activity in the surface air as a result of stratospheric intrusions, Repts. Russian Acad. Sci., 356, 390-392, 1997.

Chakina, N. P., Ivanova, A. R., Elansky, N. F., and Markova, T. I.: Transcontinental observations of surface ozone concentration in the TROICA Experiments: 2. The effect of stratospheretroposphere exchange, Izvestiya, Atmos. Ocean. Phys., 37, 1, S39-S48, 2001.

Chakina, N. P., Skriptunova, E. N., and Ivanova, A. R.: The atmospheric front objective analysis and estimation of its efficiency, Russian Meteorol. Hydrol., 7, 5-16, 2000.

Chakina, N. P., Skriptunova, E. N., and Ivanova, A. R.: Estimation of precipitation generation factors from objective analysis data, Russian Meteorol. Hydrol, 5, 22-34, 2001.

Cooper, O. R., Moody, J. L., Davenport, J. C., Oltmans, S. J., Johnson, B. J., Chen, X., Shepson, P. B., and Merrill, J. T.: Influence of springtime weather systems on the vertical ozone distribution over three North-American sites, J. Geophys. Res., 103, D17, 22 001-22 013, 1998.

so Cooper, O. R., Moody, J. L., Parrish, D. D., Trainer, M., Ryerson, T. B., Holloway, J. S., Hübler G., and Fehsenfeld F. C.: Trace gas composition of midlatitude cyclones over the western North Atlantic Ocean: a conceptual model, J. Geophys. Res., 107, D7, 10,1029/2001JD00901, 2002.

\section{Cold air outbreaks and their signature in the ozonometric data}

N. P. Chakina et al.

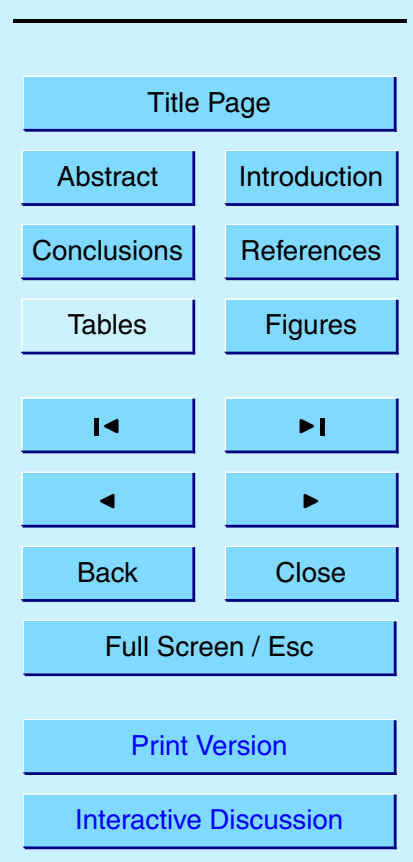

(C) EGU 2004 
Danielsen, E. F.: Stratospheric-tropospheric exchange based on radioactivity, ozone and potential vorticity, J. Atmos. Sci., 25, 502-518, 1968.

Davies, T. D. and Schuepbach, E.: Episodes of high ozone concentrations at the earth surface resulting from transport down from the upper troposphere/lower stratosphere: a review and case studies, Atmos. Environ., 28, 53-68, 1994.

Dickerson, R. R., Doddridge, B. G., Kelley, P., and Rhoads, P.: Large-scale pollution of the atmosphere over the remote Atlantic ocean: Evidence from Bermuda, J. Geophys. Res., 100, 8945-8952, 1995.

Eisele, H., Scheel, H. E., Sladkovic, R., and Trickl, T.: High-resolution lidar measurements of stratosphere-troposphere exchange, J. Atmos. Sci., 56, 319-330, 1999.

Hoinka, K. P.: Statistics of the global tropopause pressure, Mon. Weather Rev., 126, 33033325, 1998.

Holton, J. R., Haynes, P. H., McIntyre, M. E., Douglass, A. R., Rood, R. B., and Pfister, L.: Stratosphere-troposphere exchange, Rev. Geophys., 403-439, 1995.

Hoskins, B. J.: Towards a PV- $\theta$ view of general circulation, J. Atmos. Sci., 42, 2280-2288, 1991.

Hoskins, B. J., Mclntyre, M. E., and Robertson, A. W.: On the use and significance of isentropic potential vorticity maps, Quart. J. Roy. Meteorol. Soc., 470, 877-946, 1985.

Huber-Pock, F. and Kress, Ch.: An operational model of objective frontal analysis based on ECMWF products. Meteorol. Atmos. Phys., 40, 2, 170-180, 1989.

Moody, J. L., Oltmans, S. J., Levy II, H., and Merill, J. T.: Transport climatology of tropospheric ozone: Bermuda, 1988-1991, J. Geophys. Res., 100, 7179-7194, 1995.

Reiter, R.: On the mean daily and seasonal variations of the vertical ozone profiles in the lower troposphere, Atmos. Environ., 25A, 1751-1757, 1991.

Schuepbach, E., Davies, T. D., and Massacand, A. C.: An unusual springtime ozone episode at high elevation in the Swiss Alps: Contribution both from cross-tropopause exchange and from the boundary layer, Atmos. Environ., 33, 1735-1744, 1999a.

Schuepbach, E., Davies, T. D., Massacand, A. C., and Wernli, H.: Mesoscale modeling of vertical atmospheric transport in the Alps associated with the advection of a tropopause fold - a winter ozone episode, Atmos. Environ., 33, 3613-3626, 1999b.

Senik, I. A. and Elansky, N. F.: Surface ozone concentration measurements at the Kislovodsk high-altitude scientific station: Temporal variations and trends, Izvestiya, Atmos. Ocean. Phys., 37, 1, S110-S119, 2001.

\section{Cold air outbreaks and their signature in the ozonometric data}

N. P. Chakina et al.

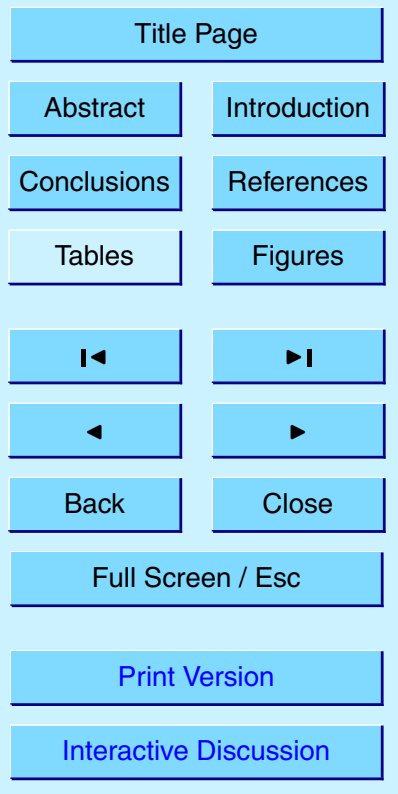

(c) EGU 2004 
Shapiro, M. A.: Further evidence of the mesoscale and turbulent structure of upper level jet stream - frontal zone systems, Mon. Weather Rev., 106, 1110-1111, 1978.

Stohl, A., Spichtinger-Rakowsky, N., Bonasoni, P., Feldmann, H., Memmesheimer, M., Scheel, H. E., Trickl, T., Hübener, S., Ringer, W., Mandl, M.: The influence of stratospheric intrusions on Alpine ozone concentrations, Atmos. Environ., 34, 1323-1354, 2000.

Wirth, V. and Egger, J.: Diagnosing extratropical synoptic-scale stratosphere-troposphere exchange: a case study, Quart. J. Roy. Meteorol. Soc., 125, 635-655, 1999.

WMO: Definition of the tropopause, WMO Bull., 6, 136, 1957.

WMO: Atmospheric ozone 1985, Rept. 16, WMO, Case Postale No. 5, Geneva, Switzerland, 1986.

\section{ACPD}

4, 267-297, 2004

Cold air outbreaks and their signature in the ozonometric data

N. P. Chakina et al.

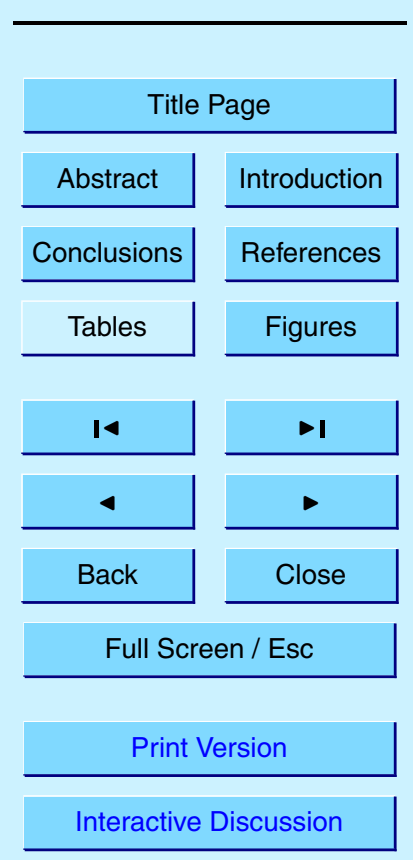

(c) EGU 2004 


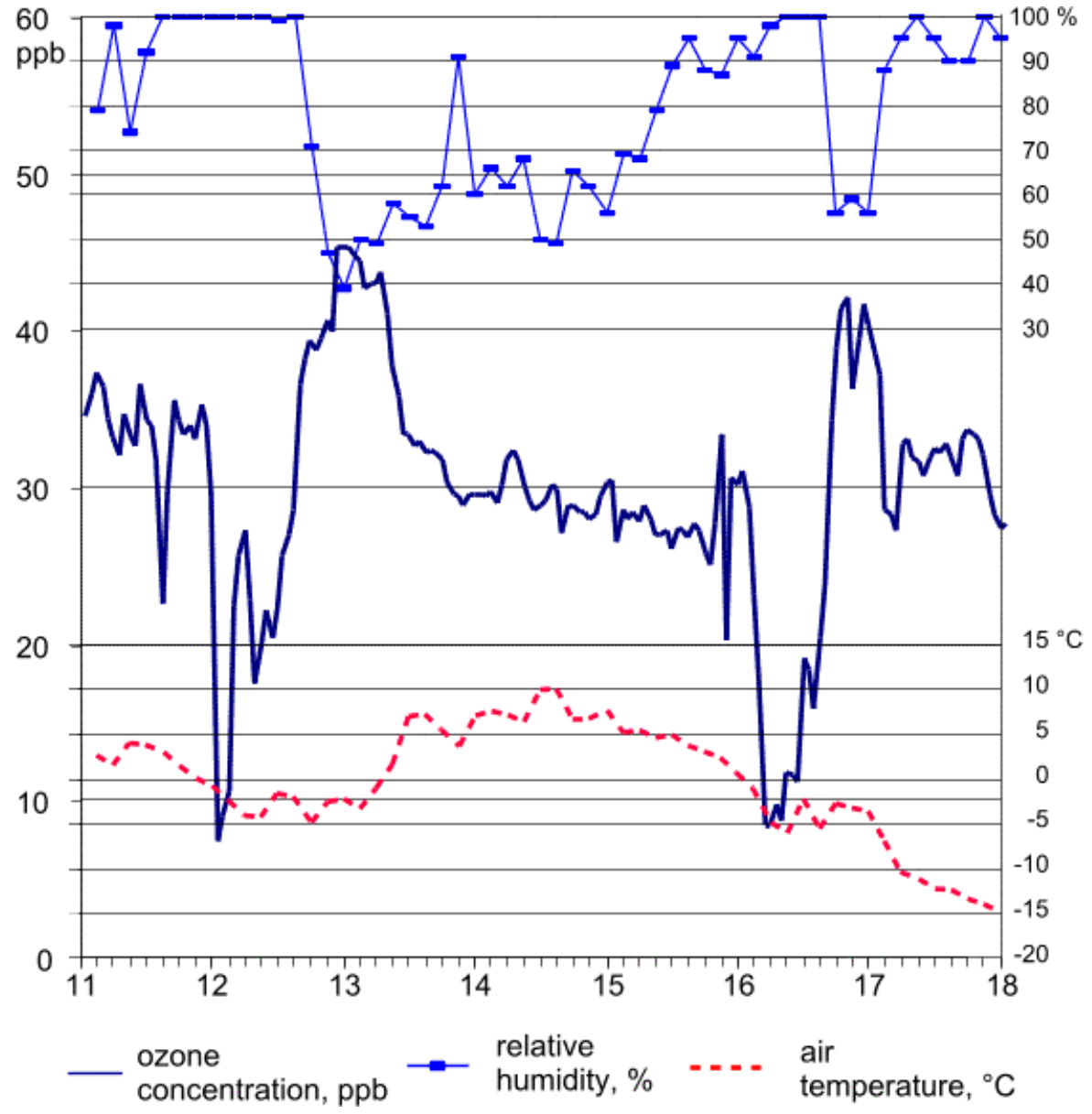

ACPD

4, 267-297, 2004

Cold air outbreaks and their signature in the ozonometric data

N. P. Chakina et al.

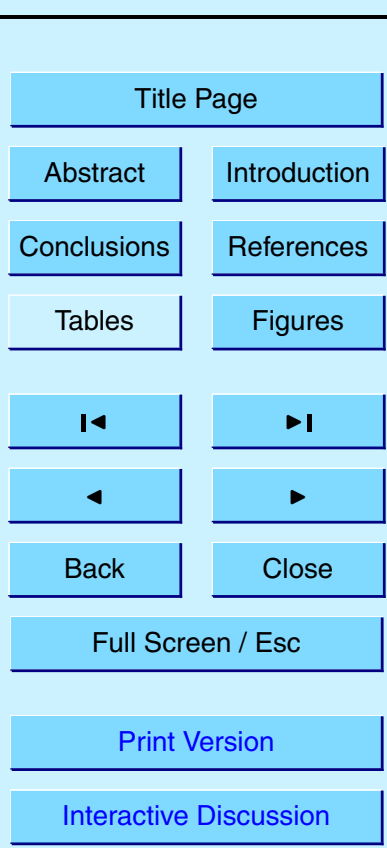

Fig. 1. Surface observations on 11-17 November 2001.

(C) EGU 2004 
(a)

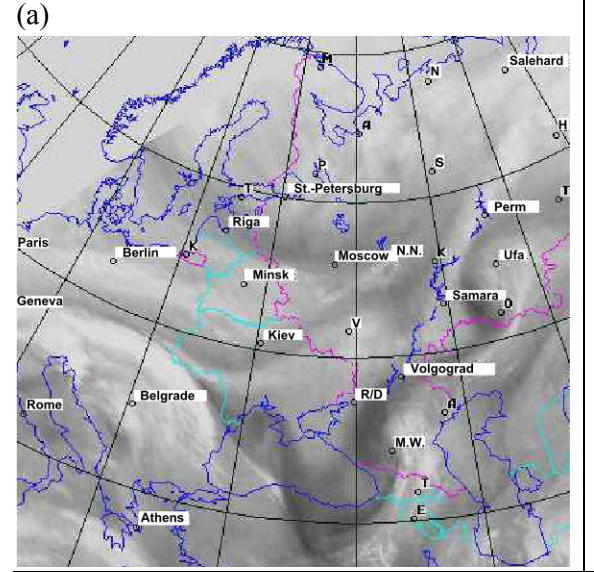

(c)

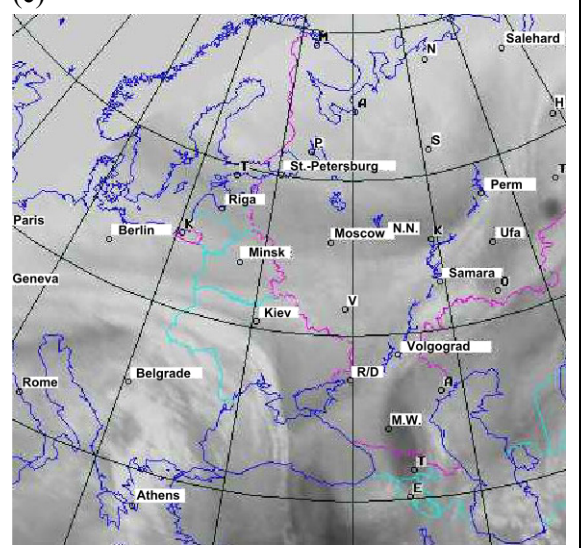

(b)

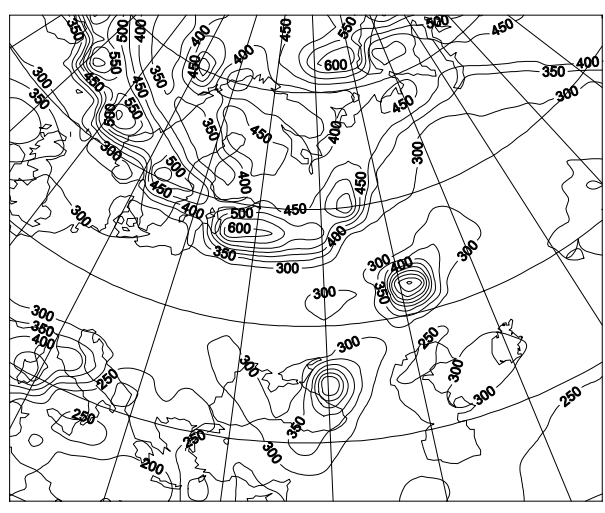

(d)

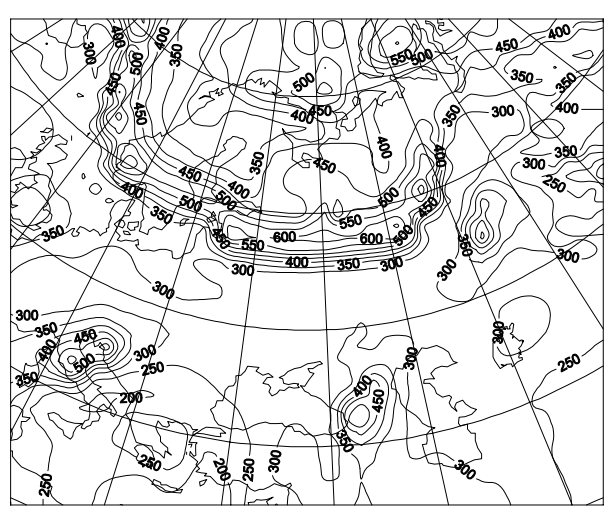

ACPD

4, 267-297, 2004

Cold air outbreaks and their signature in the ozonometric data

N. P. Chakina et al.

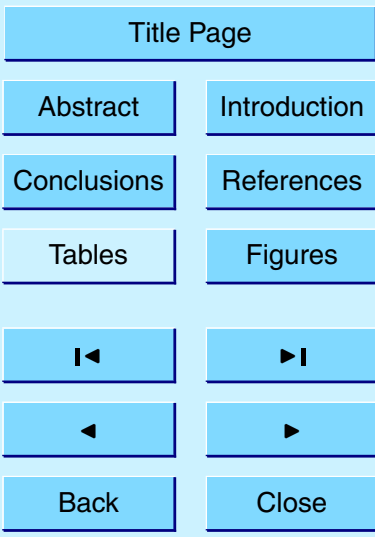

Full Screen / Esc

Print Version

Interactive Discussion

(C) EGU 2004

Fig. 2. $W V$ images (left) and $P V=1$ pvu height, $\mathrm{mb}$ (right) on 12 November 2001: 02:30 UTC (a), 00:00 UTC (b), 12:30 UTC (c), 12:00 UTC (d). In (a) and (c), the abbreviations are used for Nizhny-Novgorod (NN), Voronezh (V), Rostov-on-Don (R/D), Astrakhan (A), Tbilisi (T), Kaliningrad $(K)$, Erevan $(E)$, and Mineral Waters $(\mathrm{MW})$ - radiosonde station about $60 \mathrm{~km}$ to NE from the ozonometric station. 


\section{ACPD}

(a)

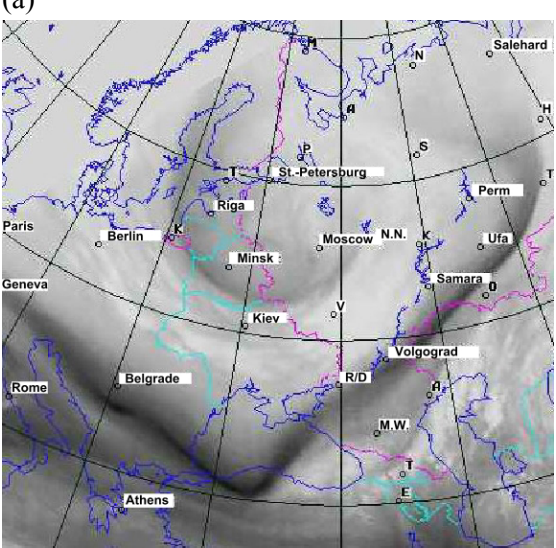

(c)

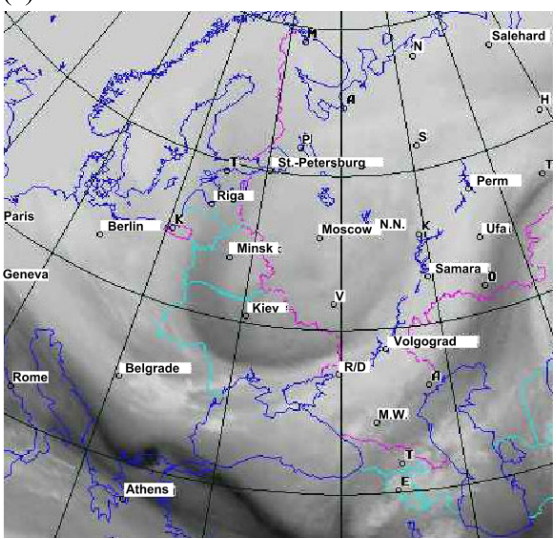

(b)

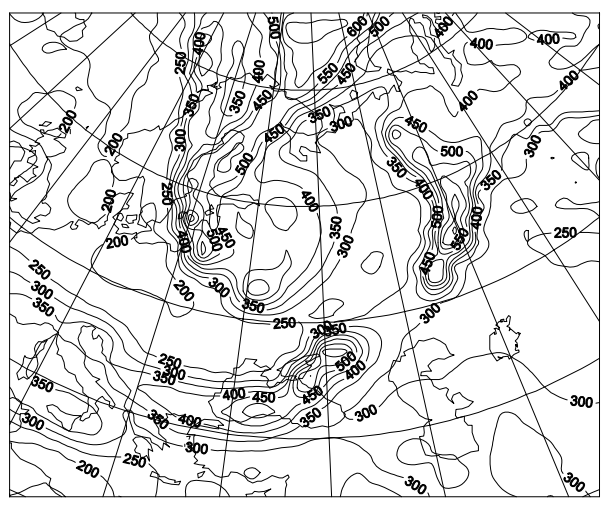

(d)

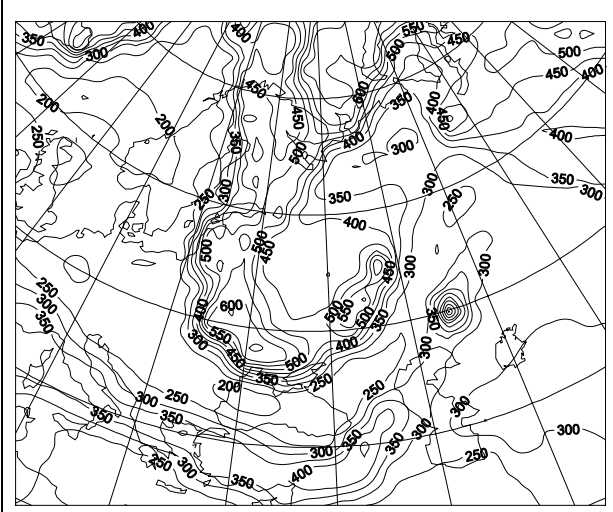

4, 267-297, 2004

Cold air outbreaks and their signature in the ozonometric data

N. P. Chakina et al.

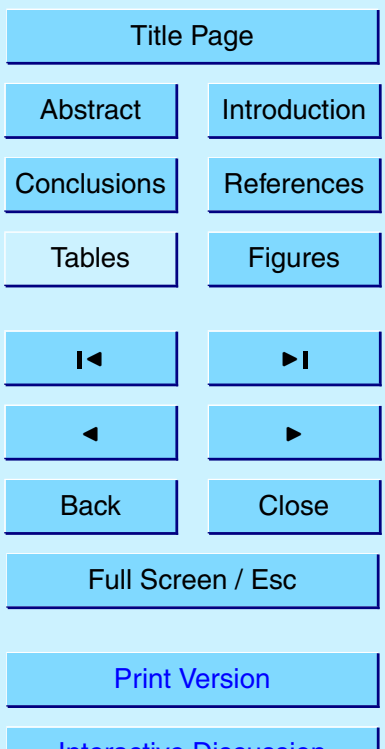

Interactive Discussion

(c) EGU 2004

Fig. 3. As in Fig. 2, but for 16 November 2001. 


\section{ACPD}

(a)

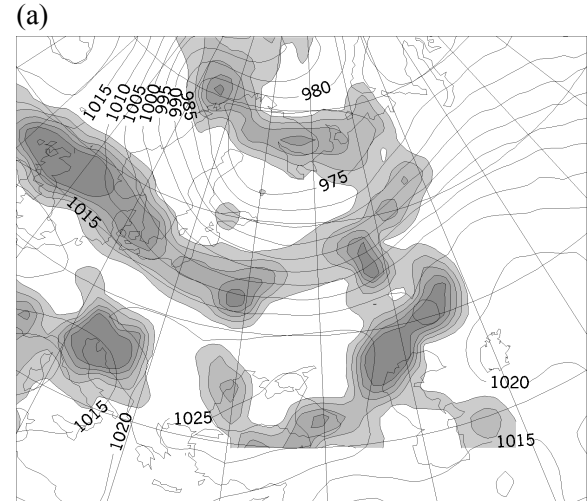

(c)

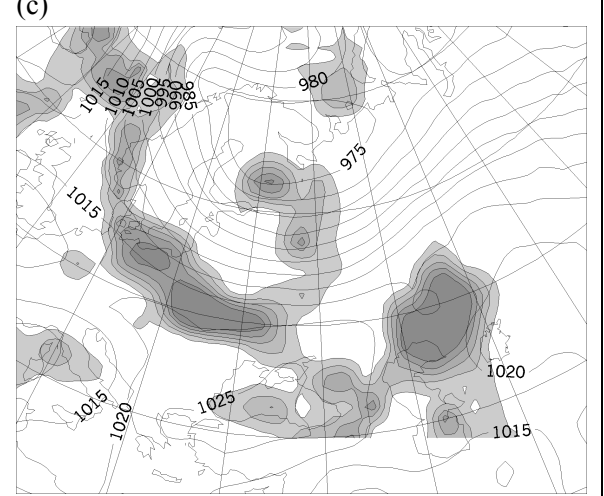

(b)

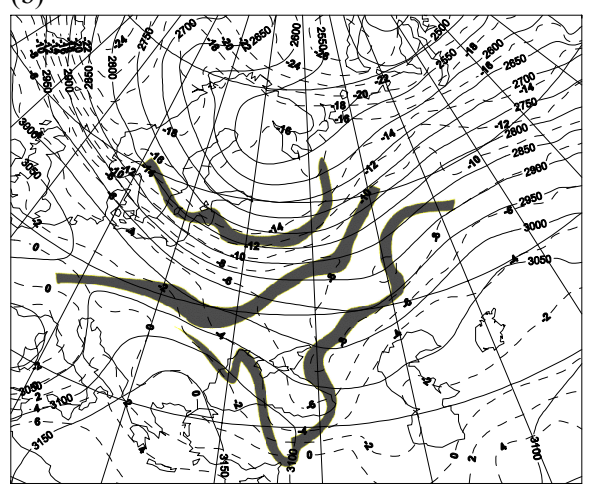

(d)

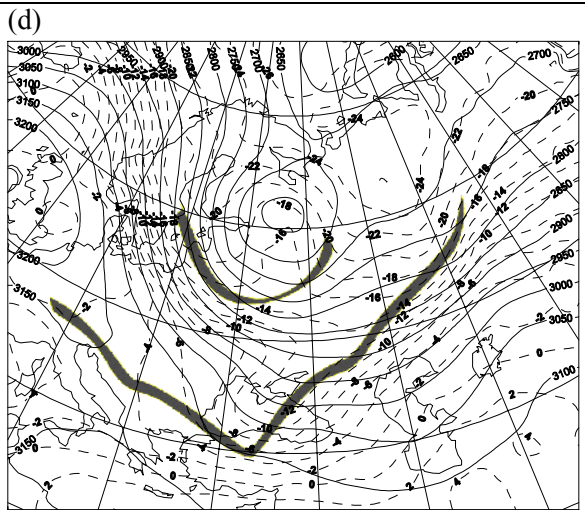

4, 267-297, 2004

Cold air outbreaks and their signature in the ozonometric data

N. P. Chakina et al.

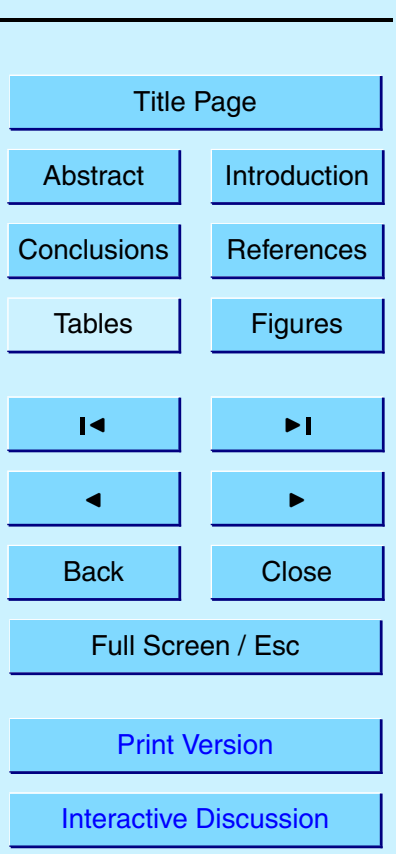

(C) EGU 2004

Fig. 4. Frontal zones (left) outlined by $F=20$ contour (increment 20 ) and $700 \mathrm{mb}$ height, $\mathrm{m}$, solid lines, and temperature, ${ }^{\circ} \mathrm{C}$ dashed lines (right) at 12:00 UTC 12 November (upper panel) and 16 November (lower panel). Positions of the dark areas at WV images are sketched by black bands. 


\section{ACPD}

(a)

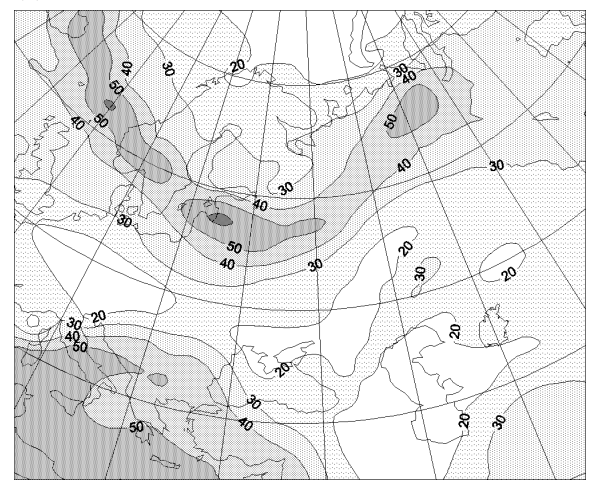

(c)

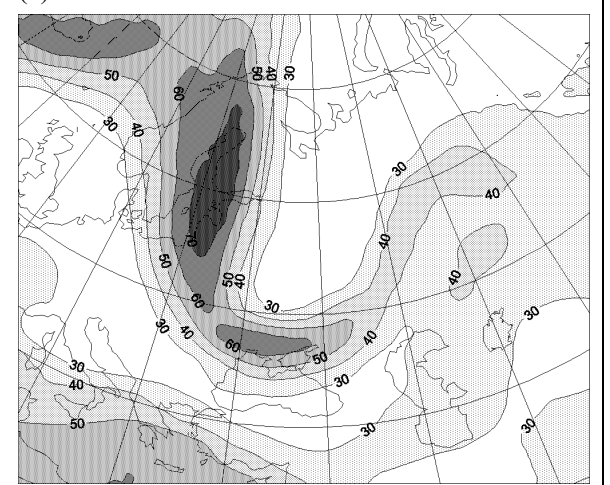

(b)

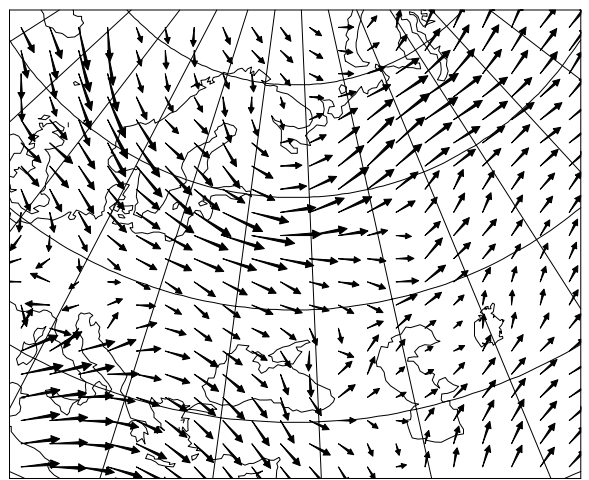

(d)

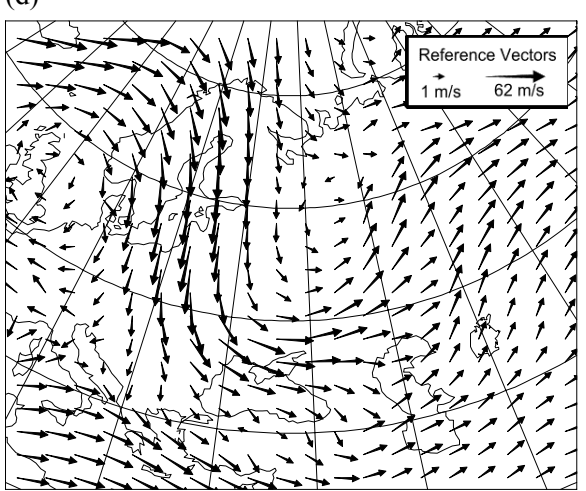

4, 267-297, 2004

Cold air outbreaks and their signature in the ozonometric data

N. P. Chakina et al.

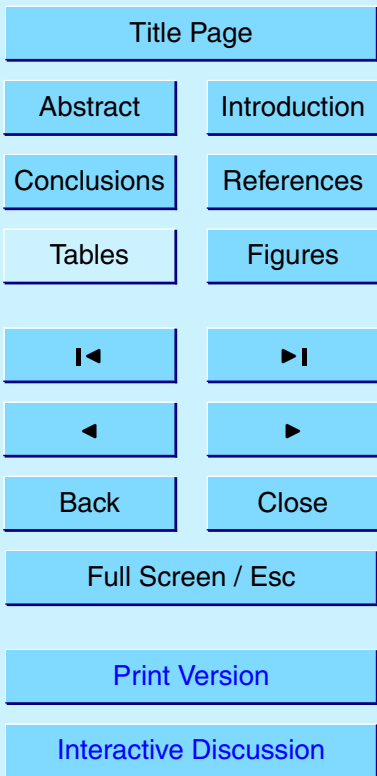

Fig. 5. Maximum wind isotachs, $\mathrm{m} / \mathrm{s}$ (left) and $300 \mathrm{mb}$ winds (right) at 00:00 UTC on 12 November (upper panel) and 16 November (lower panel).

Interactive Discussion

(c) EGU 2004 


\section{ACPD}

4, 267-297, 2004

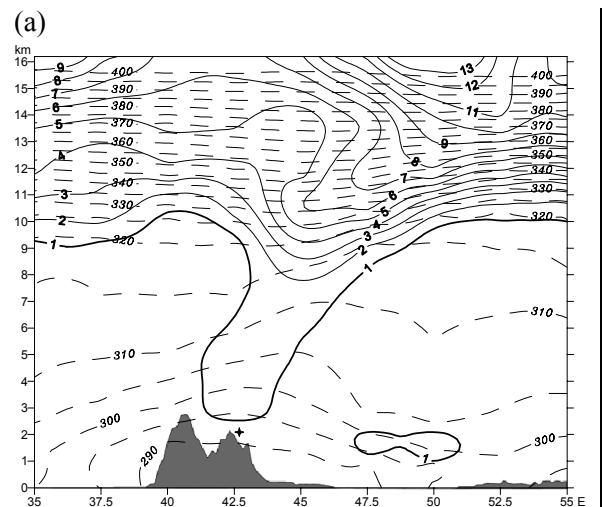

Cold air outbreaks and their signature in the ozonometric data

Fig. 6. Zonal, $45^{\circ} \mathrm{N}(\mathrm{a})$, and meridional, $42.5^{\circ} \mathrm{E}(\mathrm{b})$, cross-sections of $\mathrm{PV}$ (pvu, solid contours) and $\theta_{e}$ (K, dashed contours) at 12:00 UTC, 12 November 2001. Position of the station is shown by cross.

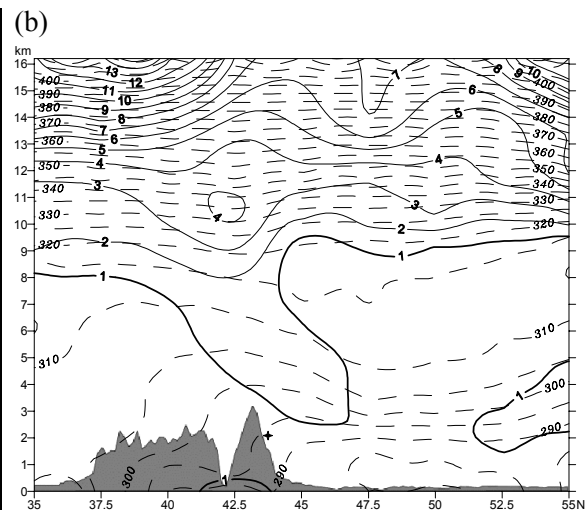

N. P. Chakina et al.

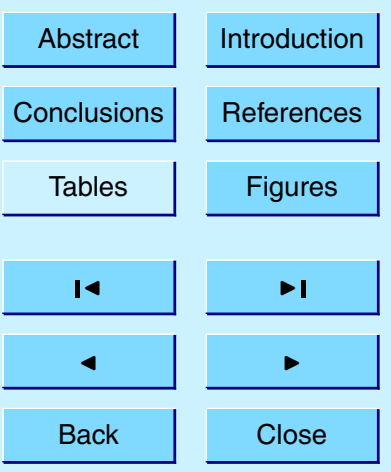

Full Screen / Esc

Print Version

Interactive Discussion

(C) EGU 2004 


\section{ACPD}

4, 267-297, 2004

\section{Cold air outbreaks} and their signature in the ozonometric data

(a)

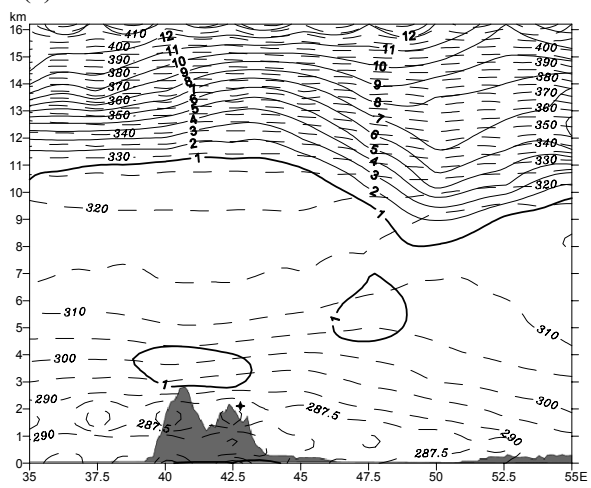

(b)

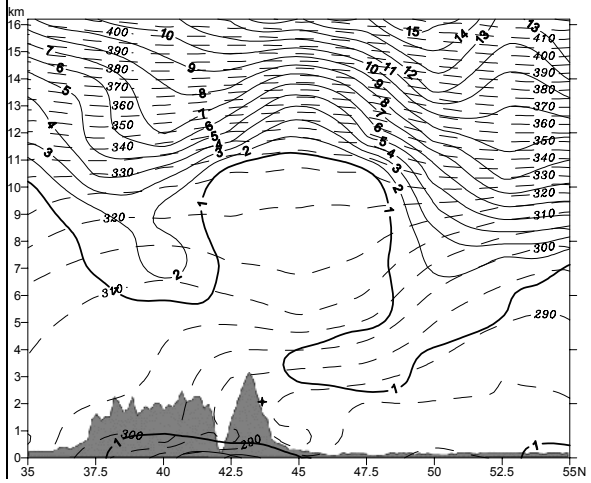

Fig. 7. As in Fig. 6, but for 16 November 2001.
N. P. Chakina et al.

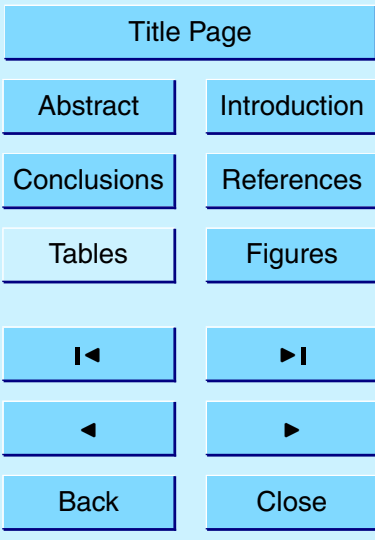

Full Screen / Esc

Print Version

Interactive Discussion

(c) EGU 2004 


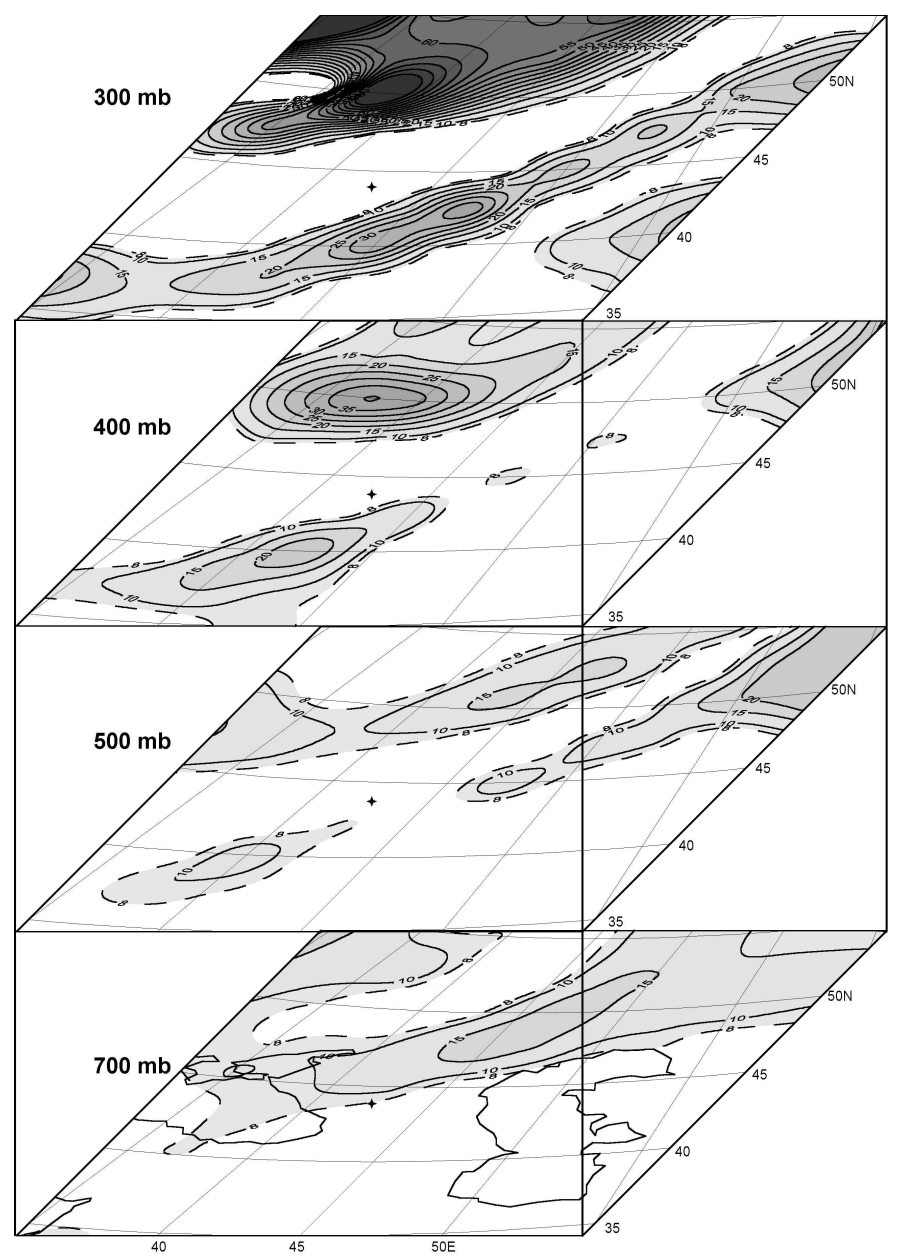

Fig. 8. The PV fields (pvu $\times 10$, the $0.8 \mathrm{pvu}$ contour dashed) at $700,500,400$, and $300 \mathrm{mb}$ levels at 12:00 UTC, 16 November 2001. Position of the station is shown by a cross.

\section{ACPD}

4, 267-297, 2004

Cold air outbreaks and their signature in the ozonometric data

N. P. Chakina et al.

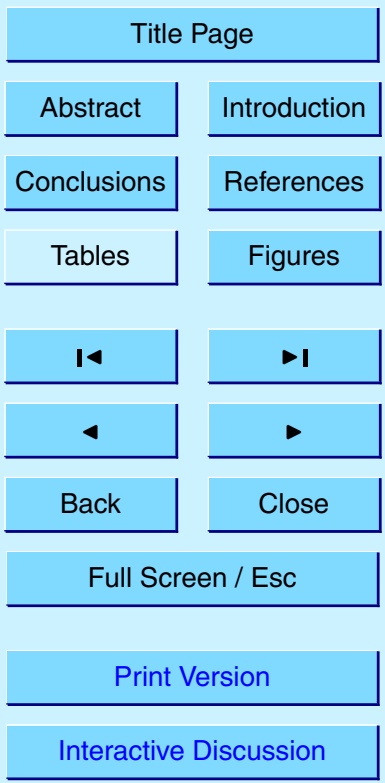

(C) EGU 2004 

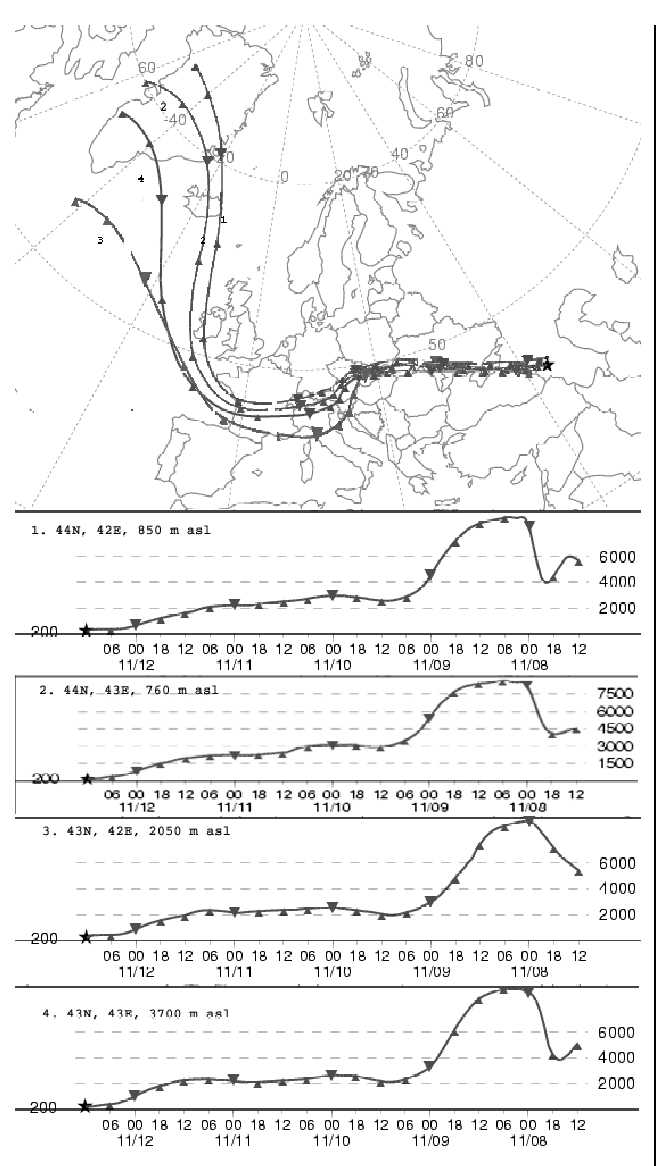

Fig. 9. Horizontal (top panels) and vertical projections of 5-day isentropic backward trajectories ending at 12:00 UTC 12 November 2001 (left) and 12:00 UTC 16 November 2001 (right) at $200 \mathrm{~m}$ a.s.l. in the points whose coordinates and elevations are given in the vertical projection panels.

\section{ACPD}

4, 267-297, 2004

Cold air outbreaks and their signature in the ozonometric data

N. P. Chakina et al.
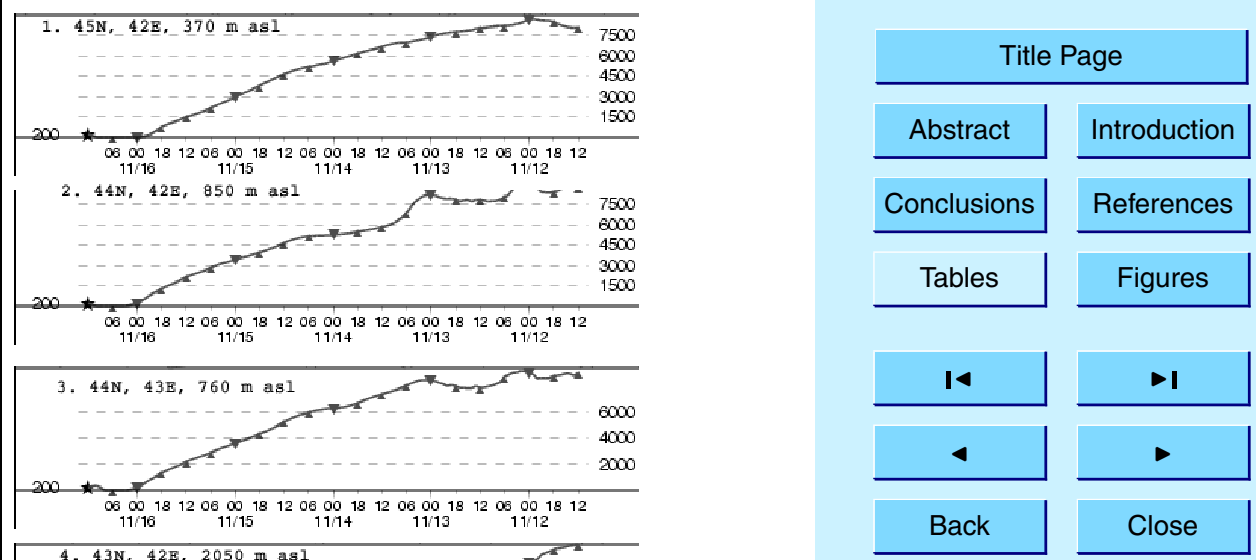

Full Screen / Esc

Print Version

Interactive Discussion

(c) EGU 2004 